\section{Article}

https://doi.org/10.11646/bde.43.1.7

\title{
Fossil mosses: What do they tell us about moss evolution?
}

\author{
MICHAEL S. IGNATOV ${ }^{1,2} \&$ ELENA V. MASLOVA ${ }^{3}$ \\ ${ }^{1}$ Tsitsin Main Botanical Garden of the Russian Academy of Sciences, Moscow, Russia \\ ${ }^{2}$ Faculty of Biology, Lomonosov Moscow State University, Moscow, Russia \\ ${ }^{3}$ Belgorod State University, Pobedy Square, 85, Belgorod, 308015 Russia \\ "E maslova@list.ru, @ https://orcid.org/0000-0003-1520-042X \\ "author for correspondence: झ"misha_ignatov@list.ru, @ https://orcid.org/0000-0001-6096-6315
}

\begin{abstract}
The moss fossil records from the Paleozoic age to the Eocene epoch are reviewed and their putative relationships to extant moss groups discussed. The incomplete preservation and lack of key characters that could define the position of an ancient moss in modern classification remain the problem. Carboniferous records are still impossible to refer to any of the modern moss taxa. Numerous Permian protosphagnalean mosses possess traits that are absent in any extant group and they are therefore treated here as an extinct lineage, whose descendants, if any remain, cannot be recognized among contemporary taxa. Non-protosphagnalean Permian mosses were also fairly diverse, representing morphotypes comparable with Dicranidae and acrocarpous Bryidae, although unequivocal representatives of these subclasses are known only since Cretaceous and Jurassic. Even though Sphagnales is one of two oldest lineages separated from the main trunk of moss phylogenetic tree, it appears in fossil state regularly only since Late Cretaceous, ca. 70 million years ago (Ma), while earlier they were found twice as small leaf fragments from Lower Jurassic (ca. $200 \mathrm{Ma}$ ) and Late Ordovician (ca. $455 \mathrm{Ma}$ ). Pleurocarpous mosses appear in fossil state near the border between Jurassic and Cretaceous, although most Cretaceous mosses belong to acrocarps. Only in Eocene amber pleurocarps become more numerous than acrocarps. Some Eocene mosses can be assigned to extant families and sometimes genera, although the majority of Eocene pleurocarps are difficult to identify up to the family, as their morphology often allows placement of a particular specimen into several different families.
\end{abstract}

Keywords: Bryophyta, evolution, paleobotany, protosphagnalean

\section{Introduction}

Since late 1990s, bryologists were provided with a bulk of new methods based on DNA sequence studies. The following 'high wave' of novel results strongly influenced bryophyte taxonomy and biogeography. Almost simultaneously, the molecular phylogenetic approach commenced to be used for the reconstruction of the evolutionary history of mosses, with dated phylogenies based on time calibration by means of some fossils (Newton et al. 2007). In this first attempt to time calibrate moss phylogenies, the oldest node in moss phylogeny was estimated as 380 (362-399) million years ago (hereafter, Ma). Later, Laenen et al. (2014) used a somewhat different methodology and estimated the age of mosses by three methods as 602, 507, and $488 \mathrm{Ma}$. This dating is in agreement with the origin of ancient Embryophytes in the Ordovician-Silurian (Kenrick \& Crane, 1997), or earlier judging from the cryptospore records (Taylor \& Strother, 2008; Rubinstein et al. 2010).

However, such dating for mosses does not coincide in general with the bulk of the paleontological data, as more or less numerous fossil moss records began to appear only during the Permian (ca. 299-252 Ma), while more ancient records are quite few. This discrepancy obviously relates, among others, to the extreme paucity of fossil moss records. Tomescu et al. (2018) provided a list of fossil bryophytes, showing that amber inclusions (known from Eocene and Cretaceous) remain the main mode of moss preservation in the period from Carboniferous to Eocene (101 out of 226 records). However, fossil mosses in amber are scarce compared with insects. For example, from Taimyr amber a single moss inclusion is known, while there are 7000 identified specimens of insects, and in Rovno amber the rate is 20 mosses vs. 36000 insects, excluding unidentified remains (data of E. Perkovsky, Mamontov \& Ignatov 2019). Krassilov \& Schuster (1984) suggested, as a putative explanation of moss rarity in fossil state compared to hepatics, that the earliest mosses perhaps evolved rapidly into drought-tolerant forms that occupied sites where fossilization was 
unlikely. However, not only xerophytic mosses may have failed to fossilize, but also species that may have grown on permanently wet rock faces, like extant Andreaeobryum Steere \& B.M. Murray (1976: 407), or on rock overhangs, often inhabited by, e.g., extant Takakia S. Hattori \& Inoue (1958: 133), avoiding competition and growing in habitats not suitable for burial.

In addition to the paucity of the fossil record, another problem with fossil moss specimens is that their morphology in most cases is not rich enough to assign them to any family and/or order with a reasonable level of confidence. The position in mosses per se is not as equivocal as for extant mosses, although among the latter there were examples of misplacements even in 20th century: the moss genus Takakia was referred to hepatics for almost forty years, and Dixon (1932) treated Haplomitrium Nees (1833: 109) (as Calobryum Nees in Gottsche, Lindenberg \& Nees (1846: 507)) as a moss. In extinct groups, the protosphagnalean genus Vorcutannularia Pogorevich ex Neuburg (1960: 66) was originally classified as a horsetail, the type species of Polyssaievia Neuburg (1956: 322) was originally described as a gymnosperm, and Diettertia J.T. Brown \& Robison (1974: 170) was thought to be a moss until Schuster \& Janssens (1989) found a bilobed structure in its leaves and therefore transferred it to hepatics. Ignatov \& Shcherbakov (2011b) described the Triassic mosses Atrichites Ignatov \& Shcherbakov (2011b: 73) and Palaeosyrrhopodon Ignatov \& Shcherbakov (2011b: 77) based on leaf fragments, but a subsequent study based on rich collections from the same locality revealed that both genera in fact are different parts of the leaves of a minute, presumably aquatic lycopod that lack stomata (Gomankov 2020).

At the same, the hundreds of cases of erroneous placements of extant mosses at genus, family, order and subclass level have been disclosed in the last two decades, after molecular phylogenetic methods became widely applied to moss taxonomy (Vanderpoorten et al. 2002, Goffinet \& Buck 2004, Ignatov et al. 2007, Goffinet et al. 2009, Frey \& Stech 2009, Kučera et al. 2019).

Despite the mentioned difficulties, the reconstruction of bryophyte phylogeny moves forward, and the aim of the present paper is to provide an overview of moss fossils (excluding spores) that may help to calibrate dated phylogenetic trees. We attempt to summarize all data on Paleozoic and Mesozoic fossils. Cenozoic records are more numerous, and for the Eocene we select for discussion only records that can be identified to genus or family, and otherwise just list publications with taxa that can be identified less precisely. The main part of the present review is compiled from Jovet-Ast (1967), Miller (1980, 1984), Krassilov \& Schuster (1984), Oostendorp (1987) Wang \& Wu (2007), Ignatov (2013), and Tomescu et al. (2018). Brief comments are given in the list below for (putative) moss fossils, along with abbreviations indicating the level of certainty of taxonomic placement, i.e. whether a given fossil is still in need to be proved to be a moss [*****] or can be assigned to division Bryophyta [!****] or any of its classes/subclasses [!!***], orders [!!!**], families [!!!!*], or genera [!!!!!], respectively.

\section{Fossil records overview}

1. Pre-Carboniferous records are limited to two mosses. They are so much apart from other fossil moss records that additional confirmation is needed to decide whether Parafunaria is indeed a moss, and whether the inferred age of the Sphagnum remains, dated as Ordovician, is correct.

***** Parafunaria R. D. Yang, J. R. Mao, W. H. Zhang, L. J. Jiang \& H. Gao (2004: 181) with one species, Parafunaria sinensis R. D. Yang in Yang et al., 2004: 181), was described rather briefly from Mid-Cambrian of China. Parafunaria has a thallus $(2 \mathrm{~cm})$ and whorled leaves at its edges [in mosses, a possible parallel could be with thallose protonema of Sphagnum, but the latter is usually less than $1 \mathrm{~mm}$ ]. Leaves are described as $15 \mathrm{~mm}$ long and 5 $\mathrm{mm}$ wide, i.e. much larger than in most moss species. The only other exceptionally large-leaved fossil species is the Permian protosphagnalean Vorcutannularia plicata Pogorevich ex Neuburg (1960: 67) with leaves up to $16 \times 8 \mathrm{~mm}$. Another unusual feature for mosses is the presence of numerous leaf veins (called "costae"), but no costa as it is usually understood in mosses ("no mid-costa" in description). The only fossil comparable in terms of multiple veins could be the Permian protosphagnalean Polyssaievia Neuburg (1956: 322). The associated algal flora characterizes the habitat as inappropriate for mosses (Tomescu et al., 2018).

[!!!!!-???] Sphagnum L. (1753: 1106). Remains that do no substantially differ from the extant species of the genus Sphagnum where described by Cardona-Correa et al. (2016) from calcareous rocks of Late Ordovician (455-454 Ma) of Wisconsin, USA. Tomescu et al. (2018) evaluated this finding with a "reservation of caution" because of the too big gap, of over 100 million years, between these remains and the next moss record in the Visean (Hübers \& 
Kerp 2012, Hübers et al. 2013). The next fossil record of an unequivocal Sphagnum occurs also after a big gap in Lower Jurassic (Reissinger 1950), more than $250 \mathrm{Ma}$ after the Ordovician record, and after that there is still a third considerable gap, for more than 100 Ma up to Late Cretaceous, when Sphagnum was found in Greenland (Arnold 1932) and Wyoming (Wilson \& Webster, 1946). There is a single record of Sphagnum in Paleocene (Boulter 1994). Only in Eocene Sphagnum records became more numerous, representing plant fragments and even peat bog deposits (Kuc 1973b, Riegel \& Wilde 2016). Interestingly, there are two findings of Sphagnum in Eocene amber (Frahm 2009, Ignatov et al. 2019), which can be assumed as only a moderately rare element of coniferous forests of early Tertiary with temperate epiphytic flora. The enigma with Ordovician (and Jurassic as well?) Sphagnum remains unanswered. If at that time plants of the Sphagnum lineage already had the structure of modern (=Cenozoic) Sphagnum, they likely grew in a different habitat not appropriate for easy fossilization. Mosses placed in or near Sphagnopsida from Carboniferous (Hübers \& Kerp 2012, Hübers et al. 2013), Protosphagnalean Permian mosses (Neuburg 1958a,b, 1960, Ignatov 1990, Maslova et al. 2012a,b, Ivanov 2018, etc.) and Triassic Sphagnophyllites likely have no apparent relationship to extant Sphagnum (see below).

$* * * * *$ Calyptra hairs. Kodner \& Graham (2001) found a high similarity of hairs from calyptras of extant Polytrichum Hedwig (1801: 88) with some Silurian and Early Devonian debris (Welleman, 1995). Hairy calyptras are known in Bryophyta in Polytrichopsida and in many families of the subclass Bryidae, but are absent in more basal lineages (Sphagnopsida, Takakiopsida, Andreaeopsida, Andreaeobryopsida, Tetraphidopsida, Oedipodiopsida), thus a proof of the calyptral origin of these Devonian hairs could be an important evidence that mosses originated substantially earlier than Devonian.

2. Lower Carboniferous records were considered to be candidates for the most ancient moss, but they are too incompletely preserved and poorly understood even for being unequivocally referred to mosses.

***** Muscites plumatus Thomas (1972: 159), from UK, is a densely foliate plant, with lanceolate leaves having a broad costa and elongate cells of unistratose laminae near leaf margin; it has nothing that would distinguish it from some Dicranidae. Hübers et al. (2013) suggested that the leaf areolation is not shown with enough detail, and Tomescu et al. (2018) marked it as a moss with question mark. The only scarcely seen areolation requires some caution, although the probability that it is a moss is rather high.

$* * * * *$ Visean cuticles. Hübers \& Kerp (2012) and Hübers et al. (2013) described cuticle fragments obtained from the bulk maceration, from Germany. These cuticle fragments had an excellent cellular preservation. They were classified in seven types that could be grouped in three major types. Unfortunately, these fragments were small-sized and did not show whole leaf shape, except one putative leaf of type B-1. This narrow lanceolate leaf lacks a costa and somewhat resembles Permian genus Viledia (see below) However, minute pores of ca. $4 \mu \mathrm{m}$ in diameter, in numbers of 30-50 per cell, evenly scattered in both elongate and subisodiametric, broadly rhombic cells make this structure difficult to refer to any known moss type. Pores of much larger size occur in type B-3, which was compared with Sphagnum, but unlike any extant Sphagnum species, one large pore in positioned in the center of a short cell in this type. Type B-2a has large rounded-hexagonal cells and can be referred, at best, to liverworts, whereas type B-2c comprises a bistratose structure and its placement in Protosphagnales is difficult to understand. Although some of the obtained fragments may belong to mosses, none of them can be assigned to any moss taxon, either extant or fossil.

3. Upper Carboniferous records are also few and limited to the genus Muscites.

!**** Muscites polytrichaceus Renauld \& Zeiller (1885: 662), from France, looks more like Mniaceae or Racopilaceae due to its leaf shape than to Polytrichum, as the species epithet suggests. However, its cells are not discernible (see also Renauld \& Zeiller 1888).

!**** Muscites bertrandii Lignier (1914: 129), from France, is represented by a single stem transverse section surrounded by rhizoids that have oblique cell walls, a unique trait for mosses.

!**** Muscites amplexifolius Ottone \& Archangelsky (2001: 220) is a widespread moss in river delta environments in Argentina, having erect spreading leaves to $5 \mathrm{~mm}$ long, with large isodiametric laminal cells. The absent (or very inconspicuous) costa provides a difficulty for its taxonomic placement, as extant polytrichoid or bryoid mosses with a similar plant habit usually have costae. The large isodiametric cells may suggest the placement in leafy hepatics, although a more or less apparent spiral leaf arrangement makes this unlikely.

74 • Bry. Div. Evo. 43 (1) (C) 2021 Magnolia Press

IGNATOV \& MASLOVA 
4. Permian protosphagnalean mosses possess traits that are absent in any other mosses and therefore are classified here as an extinct group, which descendants cannot be recognized among other moss taxa, both extant and fossil. They are referred to mosses due to rhizoids with oblique walls between cells, unistratose leaf laminae, plant habit and its variation, and comparable dimensions of stems, leaves and cells. Thus, all the genera included in this group are estimated as pertaining to Bryophyta (!****): Junjagia Neuburg (1960: 64), Vorcutannularia Neuburg (1960: 66), Protosphagnum Neuburg (1960: 75), Syrjagia Fefilova (1973: 87), Intia Neuburg (1958a: 101), Salairia Neuburg (1960: 44), Kosjunia Fefilova (1973: 85), Uskatia Neuburg (1960: 45), Polyssaievia, Bajdaievia Neuburg (1958a: 103), Bachtia Neuburg (1960: 58), Rhizinigerites Meyen in Gomankov \& Meyen (1986: 28), Palaeosphagnum Ignatov (1990: 177), and Bulbosphagnum Maslova \& Ignatov in Maslova et al. (2016: 330). One small leaf fragment from Neuburg collection was described as Muscites uniformis Neuburg: 1960: 60; it may represent one of the genera described by her, treated here as protosphagnalean, but the fragment is too small for any definite decision. The main publications on Protosphagnales include: Neuburg (1956, 1958b, 1960), Fefilova (1978), Gomankov \& Meyen (1986), Ignatov (1990), Maslova et al. (2012a, b, 2016); Maslova \& Ignatov (2013), and Ivanov et al. (2018).

Protosphagnalean mosses, as they are circumscribed here, were diverse and abundant in Lower to Upper Permian in Angaraland (localities in NE European Russia, southern and middle Siberia) and Mongolia (Durante 1976), and in Subangaraland: Uskatia was reported from NW China (Liu \& Yan 1996), and Intia from Primorsky Territory of the Russian Far East (reported of Burago in Meyen 1982). In most places they form pure deposits, and thus they should be likely interpreted as forming mires.

Among 58 fossil mosses listed by Tomescu et al. (2018) for Permian, as many as 30 are referred here to protosphagnalean, which require explanation on the content of the group. Neuburg (1960) placed her genera described from Permian in two orders, Bryales and Protosphagnales, the latter including three genera with clearly dimorphic laminal cells: Junjagia, Vorcutannularia, and Protosphagnum. Neuburg also noted that the areolation in the genus Intia, though referred to Bryales, has the specific pattern of Protosphagnum (Fig. 1). Subsequently, Fefilova (1973, 1978) described the genus Syrjagia, which has in its proximal part a Protosphagnum leaf structure while distally it is indistinguishable from Intia (Fig. 1B). Ignatov (1990) showed that this pattern is in fact common, and similar transitions were demonstrated later (Maslova et al. 2012a, Ivanov et al. 2018).

The expression of cell dimorphism within the single lamina is very diverse for different species: the dimorphism can be regular across the leaf or conversely, be greatly variable within the leaf (Figs. 1, 4), and the level of differentiation correlates with the level of regularity and differentiation of cell rows. Occasionally darker laminal cells are arranged in conspicuous rows; presumably, they worked as a conductive system within the leaf (Fig. 2). Leaves of protosphagnalean mosses were attached to the stem by a narrow zone almost equal to the width of the costa (Fig. 2). Ignatov (1990) interpreted one leaf in Protosphagnum nervatum as raised on a stalk (described as paraphyllium in Gomankov \& Meyen 1986), but that was found later to be based on an artifact. Ultimately expressed, a putative conductive system has a 'net venation' represented in the genus Polyssaievia (Fig. 3). Also, the pathways of leaf cell differentiation in protosphagnalean mosses included a pattern unknown in extant mosses: the meristematic zones with just divided cells $4-5 \mu \mathrm{m}$ wide that in extant mosses occur near leaf base (Schimper 1860, Potier 1925, Frey 1970), in protosphagnalean mosses occurred in the mid leaf (Fig. 4A-D), at apex (Fig. 4E) or at base (Fig. 4FG), as described by Maslova et al. (2012a).

Oblique cell rows are known in some extant mosses, e.g. in Mniaceae, but in protosphagnalean mosses the pattern is unique in that the oblique cell rows consist of two alternated cell types, in which one of two neighboring rows has twice the number of cells (Fig. 1D), i.e. one cell in one row and two cells from the neighboring row form triads, that further may develop a sphagnoid areolation pattern (for details see Ivanov et al. 2018). A sphagnoid areolation pattern may appear within a leaf here and there (Figs. 1, 2. 4, 5). Its presence, combined with leaf attachment to stem by the costa only and the presence of a peculiar border (Fig. 1B) are common characters of mosses referred here to Protosphagnales. In some genera with longer cells, e.g. Uskatia, the sphagnoid areolation pattern may be difficult to note, but the similarity of leaf attachment to stem, and the identical structure of the border, place them into the 'core Protosphagnales'. The border is absent in Rhizinigerites, however, the sphagnoid areolation pattern is well expressed in at least some parts of the leaves (Fig. 5C) and probably is responsible for parts of the laminal cells falling off regularly (Fig. 5A). Rhizinigerites adds one more character to this group, namely the occasional presence of leafless axes that are either totally naked or bear clusters of rhizoids (Fig. 5D, E). In addition, protosphagnalean mosses comprised in the form-genus Bulbosphagnum developed tubers, which propagate into broad stems (Fig. 6). This differs from any propagule of extant mosses, where organs of vegetative reproduction propagate by means of a single apical cells and have a constriction at the joint of propagules and subtending stem, which is absent in Bulbosphagnum (Maslova et al., 2016). In conclusion, no Protosphagnales can be recommended for the age calibration of extant subdivisions of the division Bryophyta. 

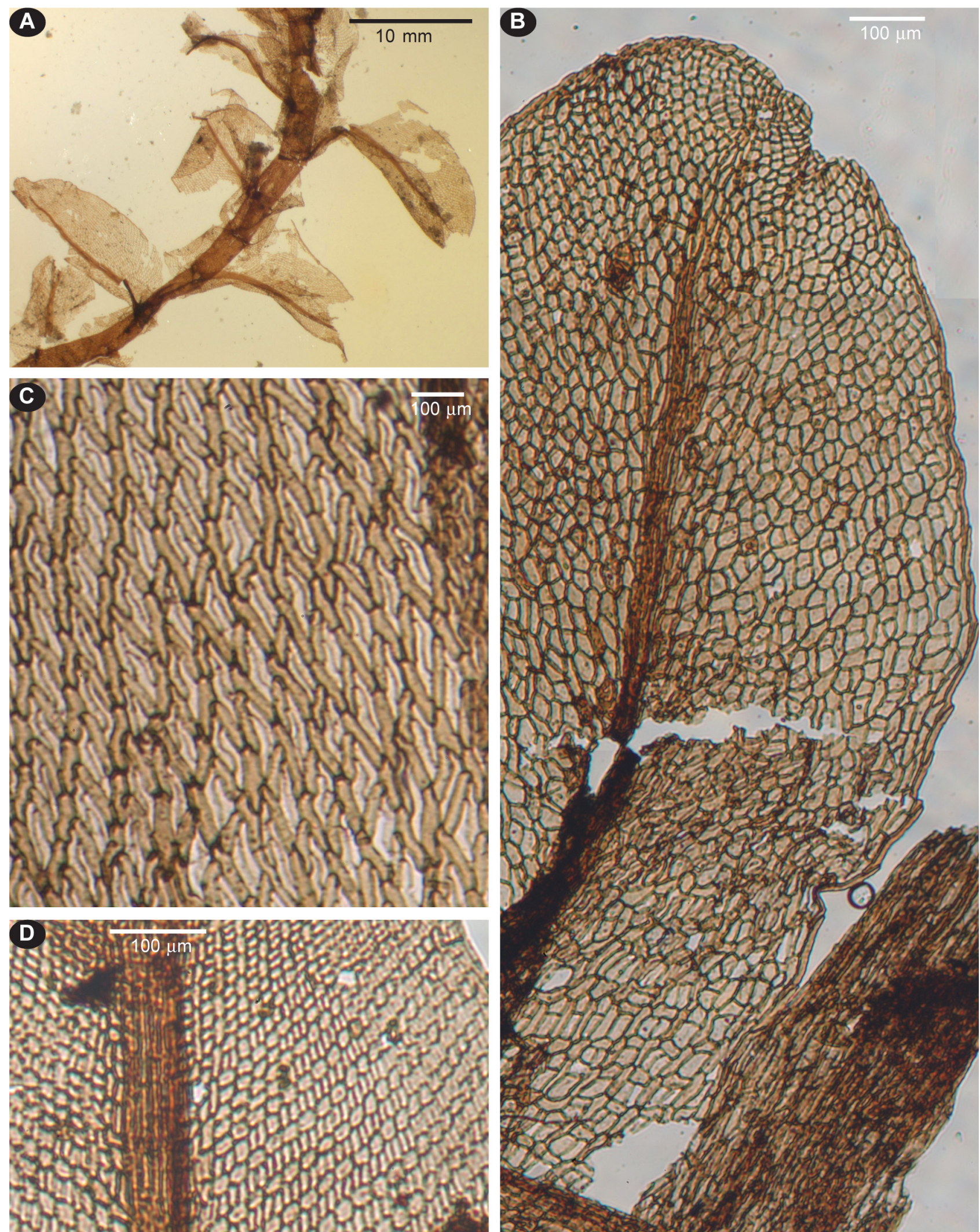

FIGURE 1. Protosphagnalean mosses showing various degrees of expression of sphagnoid areolation pattern. Protosphagnum nervatum Neuburg (1960: 75) habit (A). Intia variabilis Neuburg (1958a: 101), leaf, with more or less expressed sphagnoid areolation pattern near leaf base (B). Protosphagnum nervatum, median laminal cells (C). Kosjunia sp., median laminal cell, showing slightly developed sphagnoid areolation pattern (D). Collections: A: Viled (see Gomankov \& Meyen, 1986), Upper Permian, GIN 3774/3B-7); B-D: Adzva (MHA: see Maslova et al., 2012a), Upper Permian: B: 7643-7646 (32M_11_8_1); C: 5353 (32M_7_3_1); D: 6872 (32M_9_6_4). 

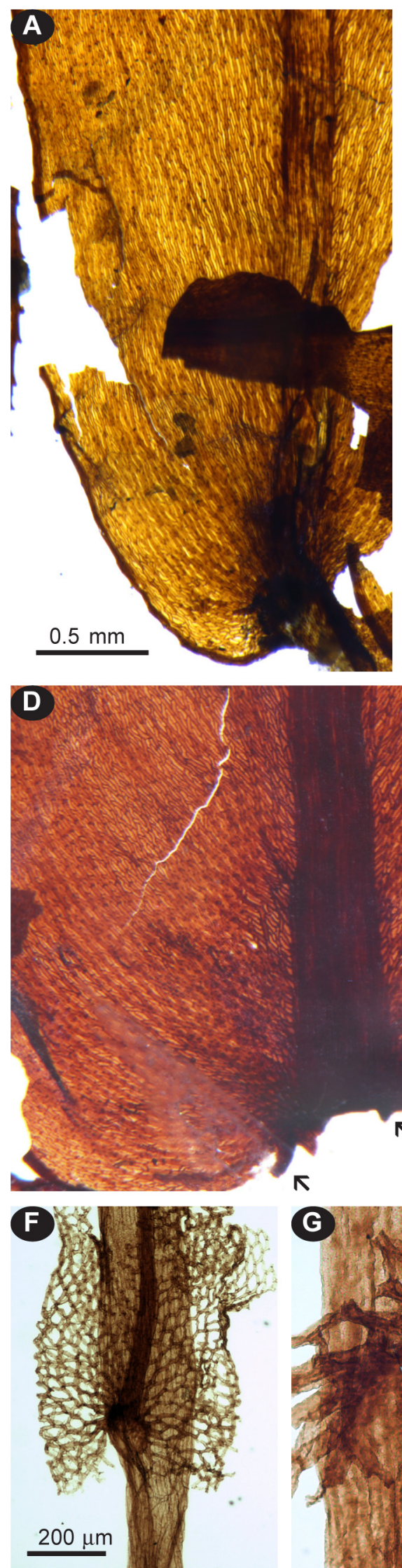
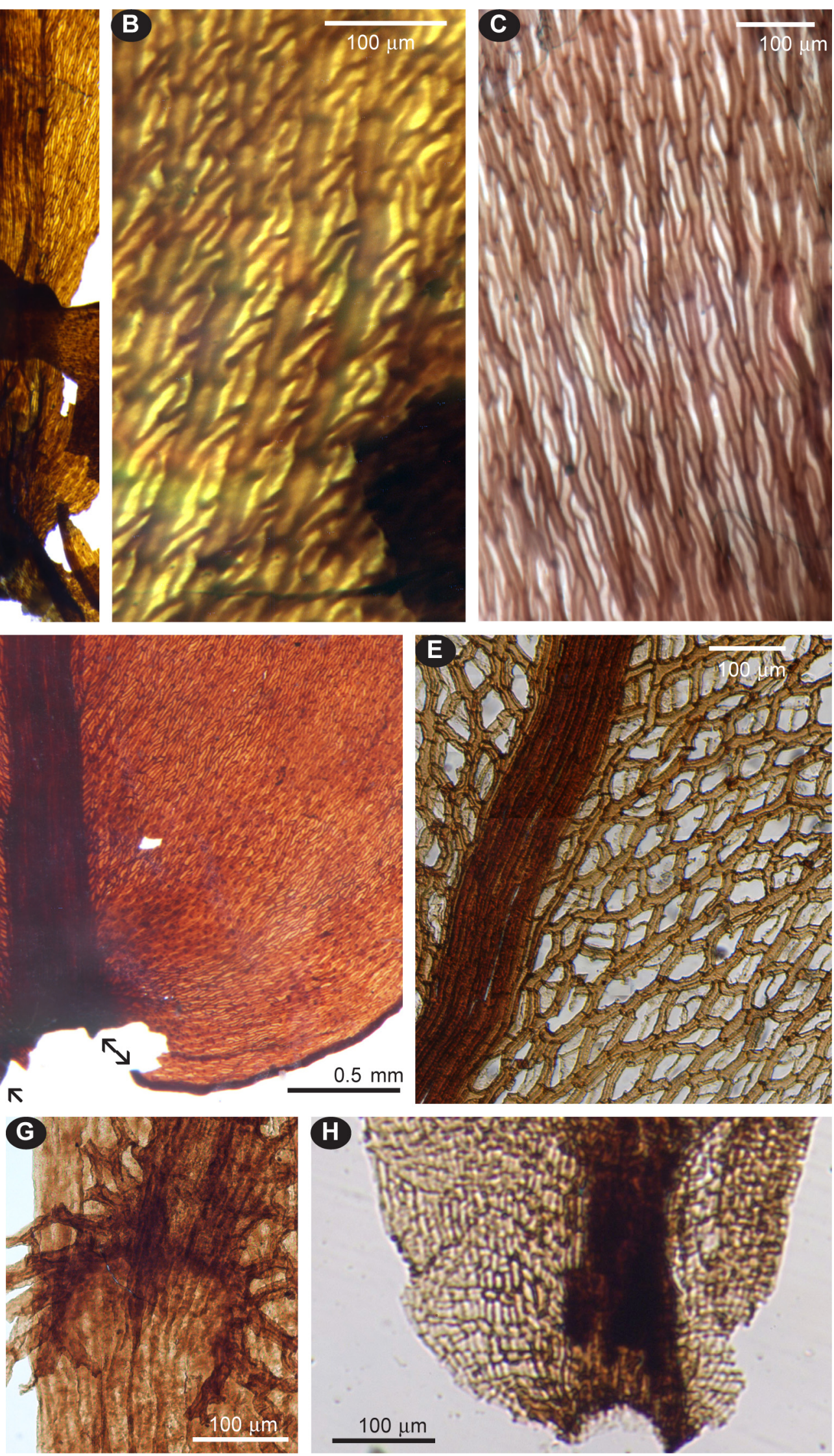

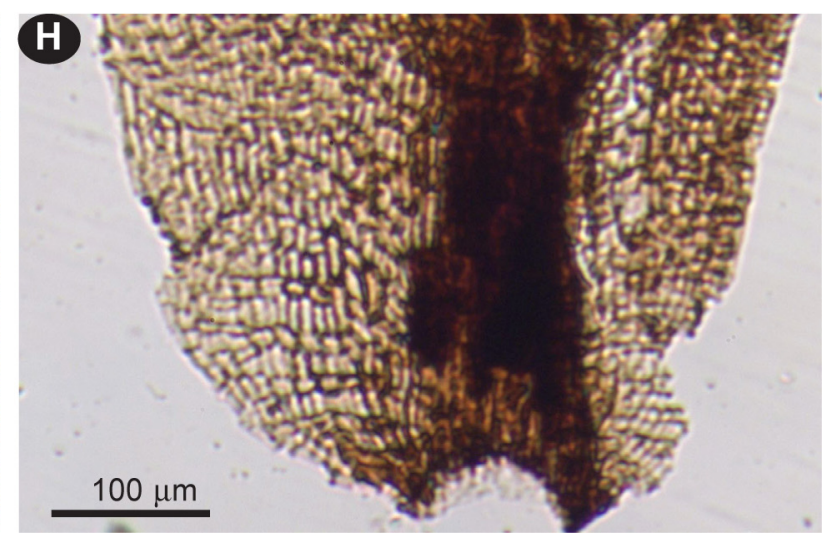

FIGURE 2. Protosphagnalean mosses, showing areolation patterns in leaves putatively responsible for conducting functions (A-C, E) and leaf attachment to stem by a narrow zone almost equal to costa width (D, F-H). Intia vermicularis (A-D, in D arrowed are border fragments, showing their adjoining almost to costa and therefore lacking decurrencies); Protosphagnum nervatum (E-G); Intia sp. (H). Collections: A-D: Pechora, Upper Permian (Neuburg, 1960), GIN \#231; E-H: Adzva (MHA: see Maslova et al., 2012a), Upper Permian: E: 38669 (32M_5_36_6); F: 32M_A_1; G: 32M_A_2; H: 4574 (32M_1_27_2). 

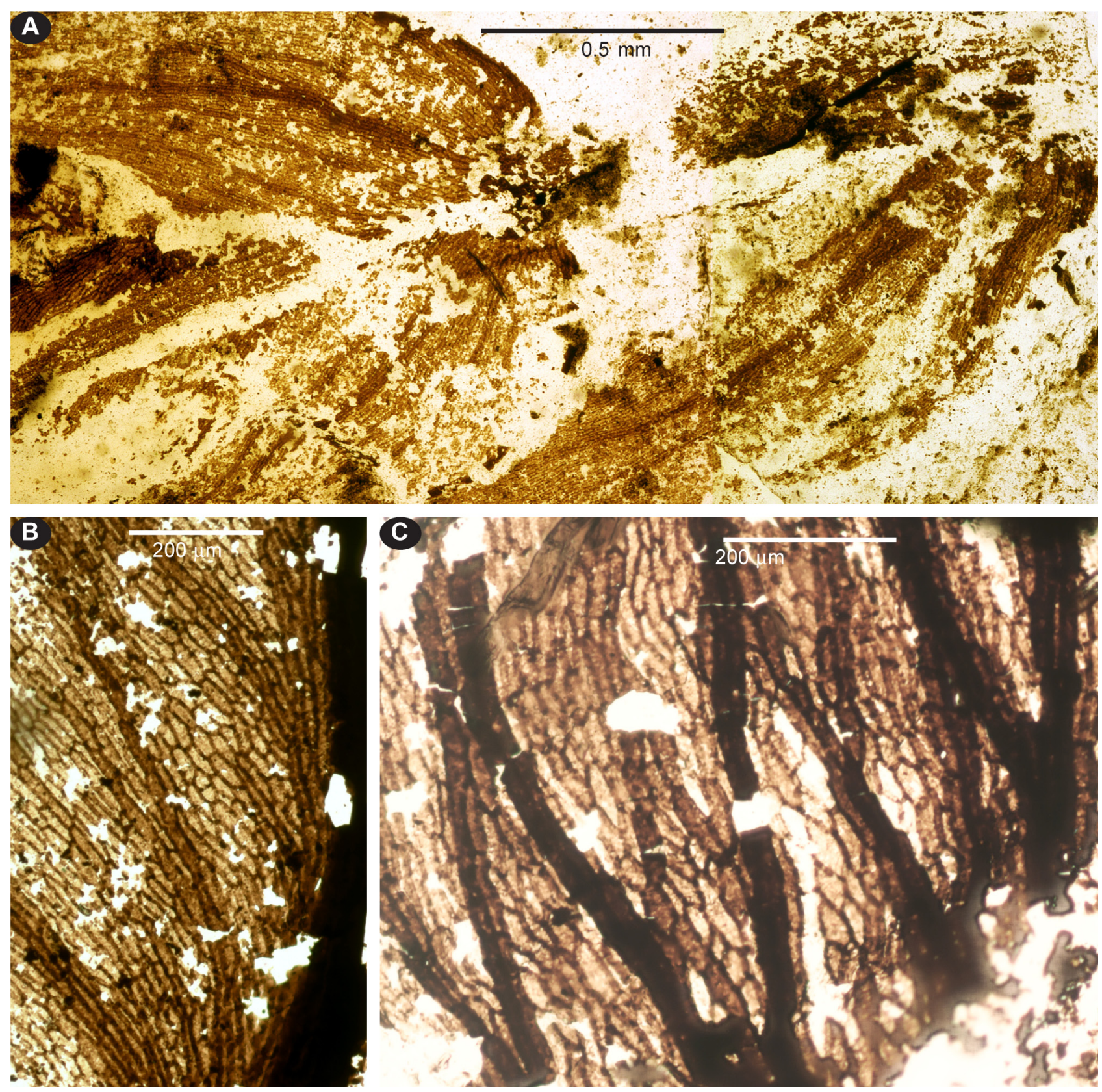

FIGURE 3. Polyssaievia deflexa Neuburg (1960: 55). Leaves and their parts with "net venation" (A-C). Collections:

Pechora coal basin (see Neuburg, 1960), Upper Permian, GIN: 3041_151c. 

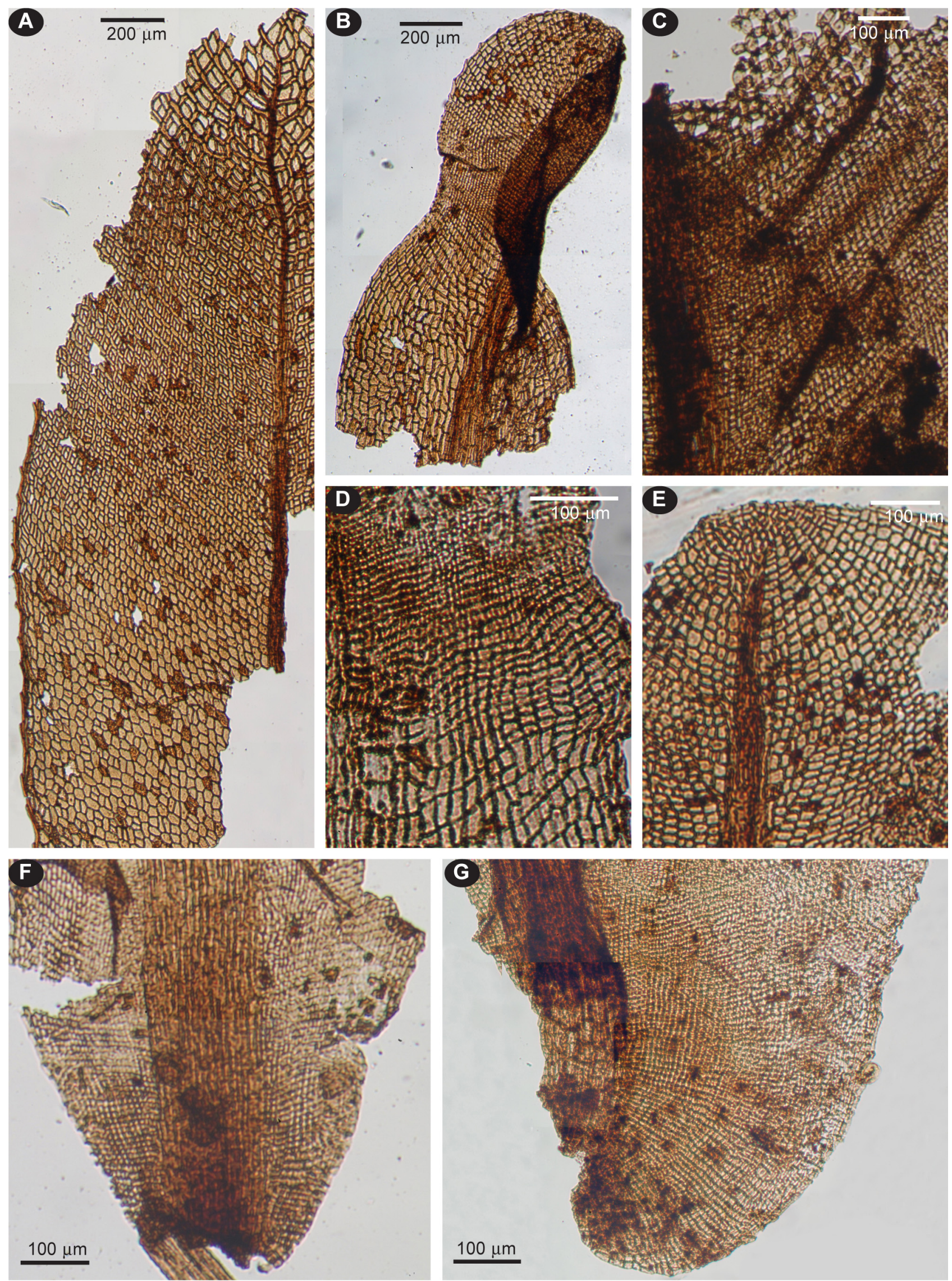

FIGURE 4. Protosphagnalean mosses, showing variation within their leaves and position of meristematic zones. Vorcutannularia sp. (A). Intia sp. (B, D, E, F). Junjagia glottophylla (C, G). Collections: Adzva, Upper Permian (MHA: see Maslova et al., 2012a), Upper Permian: A: 5903 (32M_4_35_1); B: 1759-1762 (32M_5_21_2); C: 5893-5894 (32M_4_24_ 1); D: 5572-5575 (32M_6_20_6); E: 7685 (32M_11_28_3); F: 5584-5586 (32M_6_22_9); G: 6421-6431 (32M_2_39_1). 

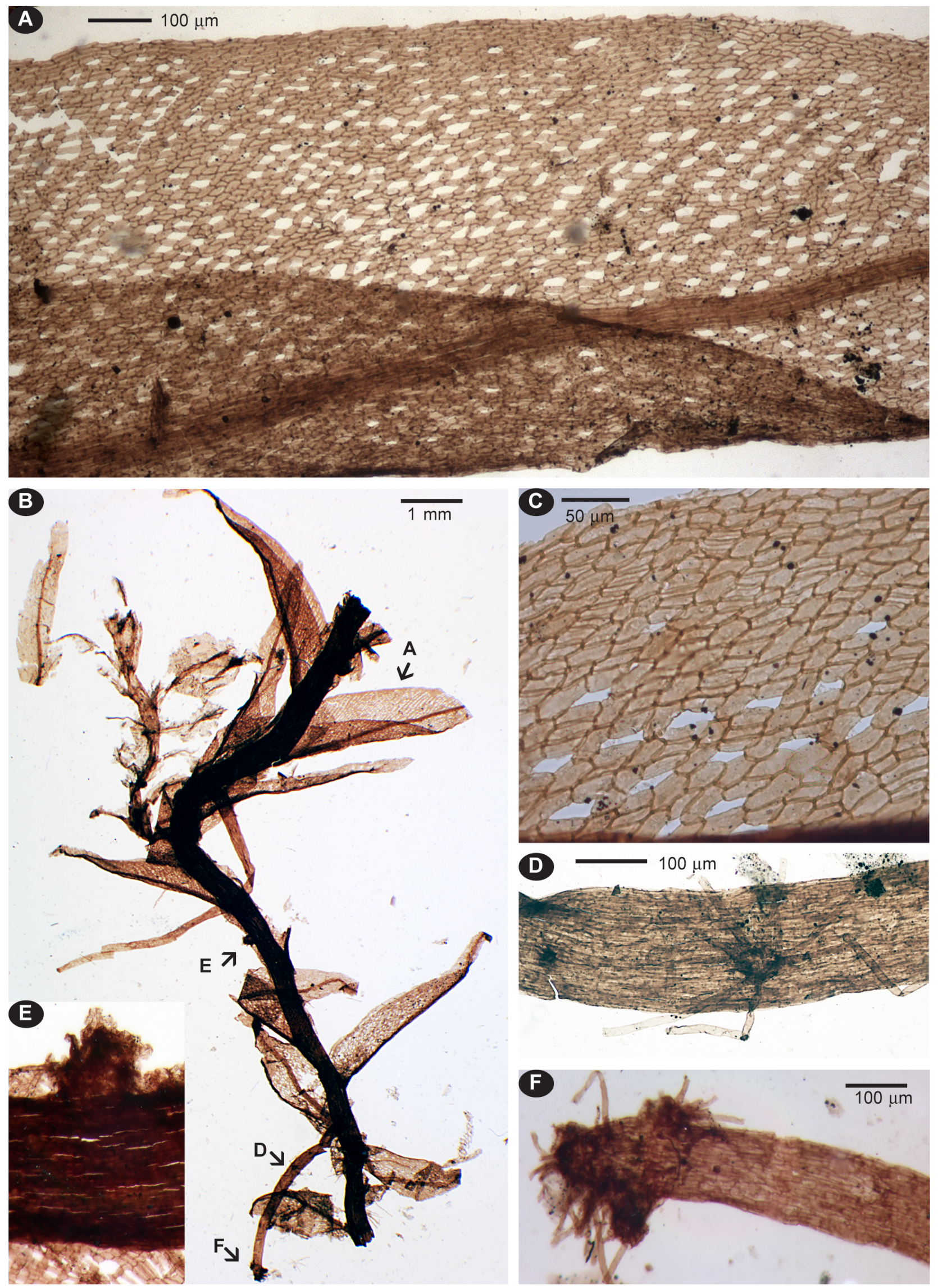

FIGURE 5. Rhizinigerites neuburgae S.V. Meyen in Gomankov \& Meyen (1986: 28). Part of leaf (A); shoot with rhizoidophores (B); areolation with sphagnoid areolation pattern (C); rhizoidophor with rhizoid cluster (D, F); primordium of branch or perianth (E). Collections: Viled (see Gomankov \& Meyen, 1986), Upper Permian, A-B \& D-F: 3774/3B-10; C: $3774 / 3 B-5)$. 

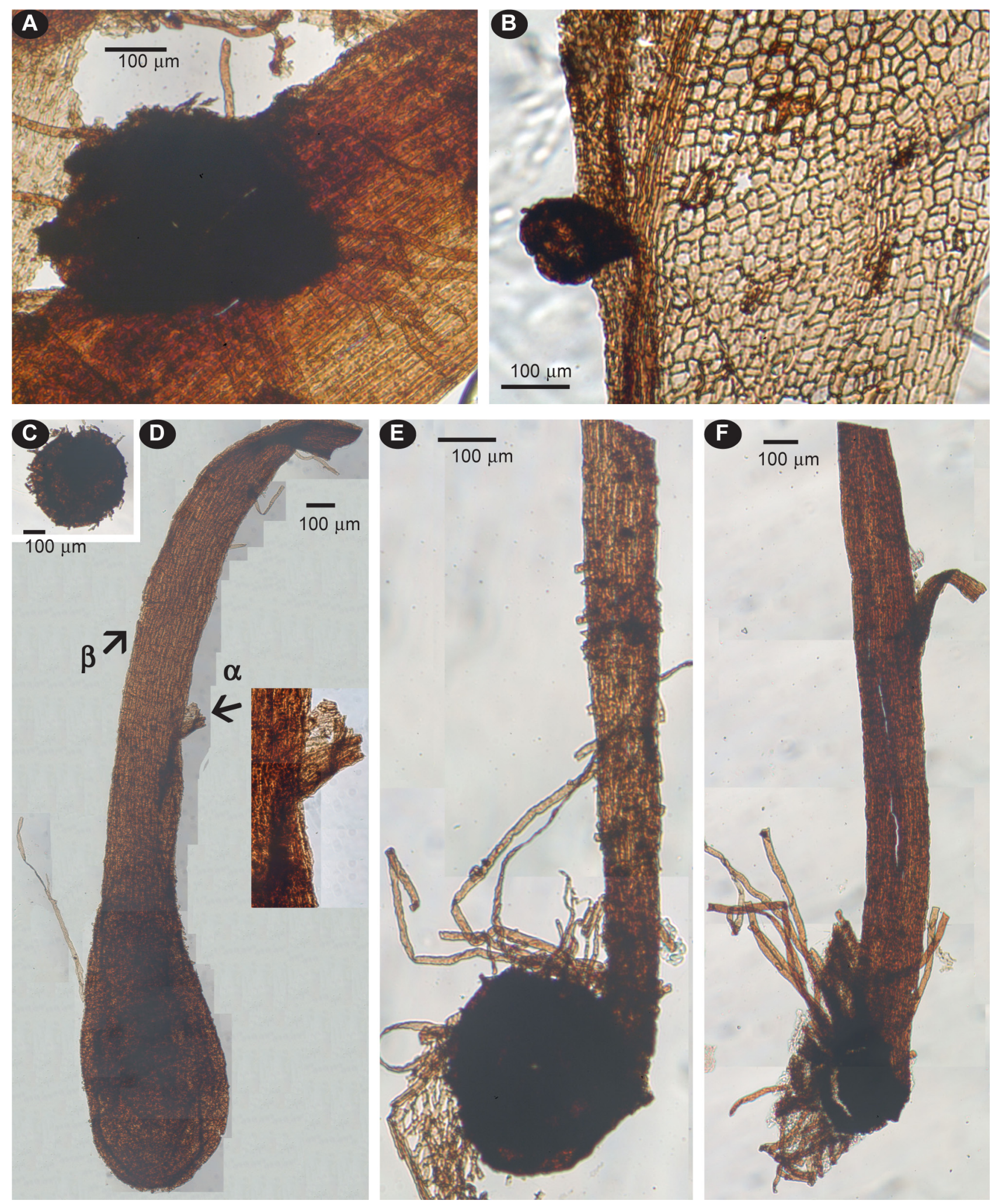

FIGURE 6. Brood bodies of Bulbosphagnum cf. polyrhizon Maslova \& Ignatov in Maslova et al. (2016: 330), developed on stem (A) and leaf (B). Separate brood body of B. polyrhizon (C). Brood bodies and stems grown from them of B. sublaeve Maslova \& Ignatov Maslova et al. (2016: 330) (D [ $\alpha$ and $\beta$ leaf remains]); B. polyrhizon (E); and a protosphagnalean stem base with rhizoids (putatively B. polyrhizon, but brood body indistinct, largely decomposed). Collections: Adzva (Upper Permian, Maslova et al., 2012a). A: 11367 (32M_16_6_2); B: 9093 (32M_12_4_6); C: 11257 (32M_16_1_11); D: 10742 (32M_12_20_1); E: 8567 (32M_12_1_7); F: 8667-71 (32M_12_2_3). 
5. Permian true mosses. About half of Permian mosses were described as having no features contradicting their placement in mosses, and in some cases they are comparable with one or several extant moss groups. The level of confidence is different between taxa with discernible leaf areolation and those where cell shape and size remain unknown, which are discussed separately.

\subsection{Permian true mosses with known laminal areolation}

\subsubsection{Gondwana}

!**** Merceria Smoot \& Taylor (1986: 1684), M. augustica Smoot \& Taylor (1986: 1684), from Antarctica, consists of transverse sections of stem and leaves. It is characterized by a moderately homogeneous costa in transverse section, leaves up to $2.5 \mathrm{~mm}$ wide, and cells elongate-rhomboidal to linear, ca. 60-160 $\times 10-15 \mu \mathrm{m}$ (average $80 \times 11 \mu \mathrm{m}$ ). The authors' suggestion of an affinity with Bryales (now equivalent of acrocarpous Bryidae) is most likely due to the oblique laminal cell ends.

!**** Palaeocampylopus Ignatov \& Shcherbakov (2009: 209) with one species, P. buragoae Ignatov \& Shcherbakov (2009: 209), from the Russian Far East, is a compression of erect shoots with cup-like terminal rosettes of short and broad leaves, similar to, e.g., perigonial leaves of Polytrichaceae (Polytrichum Hedw.) and perichaetial leaves in Dicranaceae (Campylopus Brid.). Leaf shape and fine striolation on the dorsal leaf side are characteristic of Campylopus, thus both Dicranidae and Polytrichopsida could be considered.

!**** Talchirophyllites Chandra (1995: 24), with one species T. indicus Chandra (1995: 24) from India, is compared, among extant mosses, with Atrichum P. Beauv. and Pogonatum P. Beauv., which agree with the leaf length of $8 \mathrm{~mm}$. Laminal cells are reported as rectangular, although from the illustration they may more likely be considered as almost quadrate, supporting the affinity to Polytrichaceae.

!**** Yguajemanus Christiano de Souza, Ricardi Branco \& Leon Vargas (2012: 236) with one species Y. yucapirus Christiano de Souza, Ricardi Branco \& Leon Vargas (2012: 236), from South Brazil, is a moss superficially resembling the Upper Carboniferous Muscites amplexifolius from Argentina, but differs from it in having a distinct costa, well differentiated leaf margins, and considerably smaller leaves. The cells were not described, although the original Fig. 5H in Christiano de Souza, Ricardi Branco \& Leon Vargas (2012: 236) illustrates rectangular cells 2-3:1 (ca. $20 \times 10$ $\mu \mathrm{m})$. The authors compared the species with extant Mniaceae, but their cell areolation is not similar.

\subsubsection{Angaraland}

!**** Arvildia Ignatov (1990: 150) includes two species, from NE European Russia. Both have small, lanceolate to oblong leaves with stout costa and thick-walled subquadrate cells, smooth or with shallow papillae. Rhizoids are also present. Arvildia elenae Ignatov (1990: 150) has narrowly acuminate leaves, while in A. obtusifolia Ignatov (1990: 155) the leaf is broadly rounded. This genus was originally compared with Pottiaceae (e.g. Didymodon Hedw.), although similar structures are known in other Dicranidae. Regular cell rows and papillae are similar with Andreaea Hedw., but the only moderately thick-walled cells do not support this affinity.

!**** Aristovia Ignatov (1990: 157) includes two species, A. subcordata Ignatov (1990: 157) and A. microcellulata Ignatov (1990: 159), from NE European Russia. They are represented by few almost complete, excellently preserved leaves distinguished from each other by cell size. Leaves are ovate-lanceolate, unbordered, the costa ends shortly below apex, and the cells are isodiametric and smooth.

!**** Gomankovia Ignatov (1990: 156), with one species, G. latifolia Ignatov (1990: 156), from NE European Russia, is represented by one complete, excellently preserved leaf, comparable with Funariaceae (Funariidae) or Splachnobryum (Pottiaceae).

!**** Ignatievia Ignatov (1990: 164), with one species, I. papillosa Ignatov (1990: 164), from NE European Russia, combines fragments of broad leaves with a costa and strongly prorate (or papillose) distal cell ends, resembling, e.g., Bartramiaceae, thus suggested to be a member of Bryidae.

!**** Protoochyraea Ignatov (1990: 160), with one species, P. polymorpha Ignatov (1990: 160), from NE European Russia. Leaves are variable in shape from lanceolate to broadened and lobate (similar to leaves around discoid perigonium in, e.g., Bartramiaceae), with a broadened costa of indistinct outlines, long rectangular laminal cells and unbordered, entire margins.

!**** Servicktia Ignatov (1990: 181), with four species that differ in leaf shape: S. acuta Ignatov (1990: 181), S. longifolia Ignatov (1990: 181), S. undulata Ignatov (1990: 181), and S. vorcutannularioides Ignatov (1990: 181), from NE European Russia. All species of the genus have small, moderately thick-walled isodiametric cells and a peculiar border of one row of rather large, elongate cells with oblique walls between its cells, resembling the border structure of some species of extant Fissidens Hedw. However, their placement into any extant order remains problematic. 
!**** Viledia Ignatov (1990: 163), with one species, V. minuta Ignatov (1990: 163) from NE European Russia, is known by a single lanceolate leaf with a thin costa and narrow, oblong cells with length to width ratio $>5: 1$.

\subsubsection{Euramerica}

$* * * * *$ Moss cuticles (Busche, 1968) from Germany, consisting of fragments of unistratose laminae, probably of mosses.

5.2. Permian true mosses without discernible cellular structure.

\subsubsection{Gondwana}

!**** Dwykea J.M.Anderson \& H.M. Anderson (1985: 95) includes two species having densely foliate stems with spirally arranged, erect, appressed narrow leaves to $5 \mathrm{~mm}$ long. Dwykea goedehoopensis J.M.Anderson \& H.M. Anderson (1985: 95), from South Africa, has leaves $5 \mathrm{~mm}$ long and $0.15 \mathrm{~mm}$ wide. Dwykea araroii Ricardi-Branco, Costa, Cristiano de Souza, Rohn, Longhim \& Faria (2013: 344), Brazil, was described from periglacial tundra habitats. It has leaves $1.40-4.19 \mathrm{~mm}$ long $\times 0.11-0.38 \mathrm{~mm}$ wide (measured on compression), and one lateral structure was interpreted as a sporophyte, with a capsule only $0.2 \mathrm{~mm}$ long, which is somewhat odd for a large plant (unless that it was a very young sporophyte). Besides, the description of leaf areolation is unclear. Amaral et al. (2004) and RicardiBranco et al. $(2013,2016)$ referred D. araroii to Upper Carboniferous, while a possibly Permian age was suggested by Christiano de Souza et al. (2012), an opinion endorsed by Tomescu et al. (2018). No systematic placement has been suggested for the genus; while the habit points to Dicranidae, Bryidae and Polytrichopsida cannot be excluded.

!**** Buthelezia Lacey, van Dijk \& Gordon-Gray (1975: 411) with one species, B. mooiensis Lacey, van Dijk \& Gordon-Gray (1975: 411), from South Africa. Leaves up to $7 \mathrm{~mm}$ long, ovate, thus the plant can be compared to modern Mniaceae or Permian Protosphagnales. However, lack of data on leaf areolation makes further comparison too vague.

!**** Saksenaphyllites Chandra (1995: 28), with one species, S. saksenae Chandra (1995: 28), from India. It was compared, among extant mosses, with Anoectangium Schwägr. (Pottiaceae, Dicranidae). One structure is interpreted as seta with capsule, but leaf-like structures on this "seta" are not explained.

!**** Umariaphyllites Chandra (1995: 29), with one species, U. acutus Chandra (1995: 29), from India. It was compared, among extant mosses, with Macromitrium Brid. (Orthotrichaceae, Bryidae) due to immersed large capsule-like structures. However, other groups with immersed capsules that are known in many families could not be excluded.

!**** Capimirinus Christiano de Souza, Ricardi Branco \& Leon Vargas (2012:231) with once species, C. riopretensis Christiano de Souza, Ricardi Branco \& Leon Vargas (2012: 231), from Brazil, is a compression of moss with erectspreading, oblong leaves, 1.1-2.1( -4.9 [perichaetial?]) $\times 0.5 \mathrm{~mm}$ (in average $1.4 \times 0.5 \mathrm{~mm}$ ), with a single costa and unbordered margins. The areolation was not described. The sporophyte is described as lateral, seta slightly more than $1 \mathrm{~mm}$, capsules erect, straight, $0.4 \times 0.2 \mathrm{~mm}$. The sporophyte position is not very well seen, but it does not contradict the placement of this plant into acrocarps, where many groups have lateral-looking sporophytes (Racomitrium Brid., Molendoa Lindb., Fissidens). The affinity with Dicranidae seems most likely. At the same time, the lack of capsule details and its unusually small size make the interpretation of a single capsule-like structure questionable. Such small capsules are known in extant mosses, but in small plants (e.g. in Schistostega D. Mohr), but in mosses with leaves up to $2 \mathrm{~mm}$ long the capsules are of larger size, most commonly $1-2 \times 0.5 \mathrm{~mm}$.

6. Triassic. In contrast to $100 \%$ costate leaves in Permian mosses, many Triassic mosses are ecostate.

!**** Muscites guescelinii Townrow (1959:10), from South Africa, is a moss with densely foliate stems, ecostate leaves with short and very thick-walled cells (cell wall width $11 \mu \mathrm{m}$ ), arranged in longitudinal and obliquely transverse rows. Townrow (1959) compared this moss with Leucodontaceae. However, quadrate cells are against its placement in pleurocarps. The absence of a costa and the quadrate cells may indicate an affinity with: (1) Dicranidae with broad costa, thus looking ecostate, like, e.g., Octoblepharum Hedw. (Leucobryaceae), or (2) Andreaea. The latter placements seem possible, as cells are arranged in conspicuous rows and are thick-walled; however, the even, not sinuose cell thickening is not in favor of such an affinity.

!**** Muscites brickiae Moisan, Voigt, Schneider \& Kerp (2012: 35), Kyrgyzstan. This plant is characterized by branched, remotely sub-complanately foliate stems, with widely spreading, oblong leaves $2-2.5 \mathrm{~mm}$ long and $0.6-0.8$ 
mm wide, without a costa, with elongate-rectangular cells arranged in distinct longitudinal rows. Its habit reminds of Jurassic and Cretaceous Bryokhutuliinia, but the latter genus has a distinct border that is absent in M. brickiae.

!**** Muscites sp. Moisan, Voigt, Schneider \& Kerp (2012: 35, and plate II, 4-7), Kyrgyzstan, has appressed narrow leaves, having superficially a Dicranidae habit.

!**** Muscites uralensis Turutanova-Ketova (1958: 677), described from the Ural Mountains in Russia. The illustration gives no clue to the species affinity.

!**** Moss cuticles (Bomfleur et al. 2014, Fig. 2 and 4A-F) from East Antarctica. They represent at least five different mosses, as illustrated and briefly discussed in the publication, but none shows apparent affinities to extant groups of mosses.

$* * * * *$ Moss cuticles (Bomfleur \& Kerp 2010, Plate 16, Figs. 1-3) from Late Triassic of Antarctica are represented by unistratose fragments, putatively bryophytes. Cells are irregularly round-hexagonal, 15-20 $\mu \mathrm{m}$, comparable with areolation of acrocarpous mosses. However, no costa or leaf border is seen, thus the width between costa and leaf border is no less than $2 \mathrm{~mm}$, which means that the leaf was at least $5 \mathrm{~mm}$ wide. Such a size makes an attribution to mosses unlikely.

***** Sphagnophyllites D.D. Pant \& N. Basu (1976: 346) with one species, S. triassicus D.D. Pant \& N. Basu (1976: 346), from India, is difficult to evaluate. The leaf size, $3.8 \mathrm{~mm}$ long $\times 2.5 \mathrm{~mm}$ wide exceeds the size known in extant Sphagnum, and hyaline cells are described as isodiametric, ca. $100 \mu \mathrm{m}$, surrounded by $4-6$ dark cells to $88 \mu \mathrm{m}$ long $\times$ $42 \mu \mathrm{m}$ wide. This combination of characters may suggest to place Sphagnophyllites into protosphagnalean rather than into sphagnalean mosses, but a protosphagnalean affinity is rejected by the absence of a costa.

!**** Tricostium triassicum Ignatov \& Shcherbakov (2011b: 78), from Mongolia (Yamanus). Leaves are oblong, with a strong central costa and weaker submarginal costae reaching 0.8 leaf length; laminal cells ca. $13 \mu \mathrm{m}$ wide, quadrate to short rectangular, thick-walled.

!**** Yamanusia crassicostata Ignatov \& Shcherbakov (2011b: 68), from Mongolia (Yamanus). Leaf broadly ovate, with small isodiametric cells and a strong costa.

The Lower Triassic Atrichites triassicus Ignatov \& Shcherbakov (2011b: 75) and Palaeosyrrhopodon grossiserratus Ignatov \& Shcherbakov (2011b: 77) from Yamanus, Mongolia, were re-evaluated by Gomankov (2020) using additional Upper Permian specimens from the same locality, who demonstrated that both collections, originally described by few leaf compressions on one slab, belong to Lycophyta (despite the fact that the leaves lack stomata).

7. Jurassic and Cretaceous. These two periods are combined in this review, as many records are from their border. Lower Jurassic records are few: Sphagnum leaf fragments (Reissinger 1950), discussed above with the Ordovician Sphagnum, and Chinese Stachybryolites and Mnioites without discernible cellular structure. For the Jurassic and Cretaceous periods, we arrange genera by the degree of the certainty in a fossil moss placement: from those that can be referred to genus, to those which may be placed in the division Bryophyta.

\subsection{Genus level}

!!!!! Campylopodium (Müller [1848: 429]) Bescherelle (1873: 189), comprises 4 good and few more dubious extant species as well as one fossil species, C. allonense Konopka, Herendeen \& Crane (1998: 715), Upper Cretaceous, USA. The latter shows a perfectly preserved peristome with "classical" dicranoid striolation shown with SEM images.

!!!!! Cynodontium Bruch \& Schimper in Schimper (1856: 12) includes about 30 extant species, one Eocene fossil (see below) and also C. luthii Bippus, Rothwell \& Stockey (2021), from Upper Cretaceous of Alaska, USA. Cross sections of permineralized fossil show a complex stricture of costa and bistratose margins that fit morphology of some extant species.

\subsection{Family level}

!!!!* Calymperites burmensis Heinrichs, Schäfer-Verwimp, Hedenäs, Ignatov \& A.R. Schmidt (2014c: 261), from Myannar, mid-Cretaceous amber, is known from rich collections, showing a gametophyte structure that is similar to extant Calymperaceae by attenuate leaf tips.

!!!!* Eopolytrichum Konopka, Herendeen, Merrill \& Crane (1997: 490) with one species, E. antiquum Konopka, Herendeen, Merrill \& Crane (1997: 490), from USA, Upper Cretaceous. Both gametophyte and sporophyte (perfect preservation allowed SEM images as well) are obviously of Polytrichaceae, although with a combination of characters not known in any extant genus. Phylogenetic analyses of Bippus et al. (2018) found Eopolytrichum to be nested within Polytrichum, thus for the calibration purposes the age of this fossil can be applied for the clade Polytrichum + Eopolytrichum. 
!!!!* Kulindobryum Ignatov in Mamontov \& Ignatov (2019: 351), with the only species $K$. taylorioides Ignatov in Mamontov \& Ignatov (2019: 352), Middle or Upper Jurassic, Transbaikalia, Russia. A morphotaxon for dispersed capsules, some having 32 peristome teeth, contorted and loosely appressed to capsule wall from outside, a conic to shortly rostrate operculum and a mitrate-cucullate calyptra. The species epithet refers to the similarity of peristome structure with some species of extant genus Tayloria Hooker (1816: 144) in the Splachnaceae.

!!!!* Meantoinea Bippus, Stockey, Rothwell \& Tomescu (2017: 585), with one species, M. alophosioides Bippus, Stockey, Rothwell \& Tomescu (2017: 585), Lower Cretaceous of Canada (Vancouver Island). Cross sections of permineralized fossil show a moss with brood bodies and typical structure of Polytrichaceae, very similar to Alophozia Cardot ex Sérgio, a Macaronesian endemic and the most basal genus in Polytrichaceae phylogeny. An additional expanded discussion of the phylogenetic position of Meantoinea was published by Bippus et al. (2018).

!!!!* Muscites sp. 1-3 (Kadlecová, 2020: 39; 2020: 40; 2020: 41), from Cretaceous of James Ross Island in Antarctica and from Czech Republic. The fossils comprise shoots with remote small leaves ca. $1 \mathrm{~mm}$ long, with a stout costa, and overall similarity to genera of Mniaceae: Rhizomnium (Mitt. ex Broth.) T.J. Kop., Cinclidium Sw. or Cyrtomnium Holmen (the geniculate stem in upper part is especially similar to the latter genus).

!!!!* Tricarinella Savoretti, Bippus, Stockey, Rothwell \& Tomescu (2018: 1276), with one species, T. crassiphylla Savoretti, Bippus, Stockey, Rothwell \& Tomescu (2018: 1276), Lower Cretaceous, Canada (Vancouver Island). Cross sections of permineralized fossil, showing homogeneous costa in transverse section. Consistence with other characters of Grimmiaceae suggested the placement in this family.

\subsection{Order level}

!!!** Unnamed Leucobryaceae Tomescu (2016: 5), Lower Cretaceous of Canada (Vancouver Island). The anatomically preserved material, comprising both surface and transverse sections, shows a leucobryoid structure and was compared with some genera of the Leucobryaceae, namely Leucobryum Hampe (1839: 42), Cladopodanthus Dozy et Molk. (1846: 79), Holomitriopsis H. Rob. (1965: 75), and Steyermarkiella H. Rob. (1965: 75) (Tomescu, 2016). Transverse section in distal part of leaves, however, comprise a triangular, not quadrate shape of chlorocysts, which suggest affinity to Leucophanaceae s.l., especially to Octoblepharum (sometimes separated to its own family Octoblepharaceae, nom. illeg.). Thus despite a highly specific leucobryoid leaf structure, its presence in more than one family allows the placement of these fossils only up to the ordinal level, in Dicranales.

!!!** Livingstonites Vera (2011:123), was described with one species, L. gabrielae Vera (Vera, 2010), Lower Cretaceous, South Shetland Islands (Antarctica). This is a small moss, known from both habit and cross sections, with stem ca. $150 \mu \mathrm{m}$ in diameter, with central strand, leaves narrowly linear to subulate, ca. $5 \times 0.2 \mathrm{~mm}$, showing elongate laminal cells and complex costa differentiation, thus allowing placement in Dicranales (former Dicranaceae s.1.). Affinity to other groups are less likely because of the following structural differences: Grimmiales have a simpler costa structure; Timmiales have a complex costa anatomy, but are larger plants with distally isodiametric and mamillose cells; Bryales have either shorter cells in the distal lamina (e.g. in Bartramiales, Meesiaceae) or broader leaves (Mielichhoferiaceae), while setaceous leaves with long laminal cells are known in many genera of Dicranales. Recently, Livingstonites sp.1 and sp. 2 were reported from Cretaceous of James Ross Island in Antarctica and from Czech Republic (Kadlecová 2020), although both habit and the very distant localities make the placement of these fossils in Livingstonites highly doubtful.

!!!** Vetiplanaxis N.E. Bell (2007: 518) includes four species from mid-Cretaceous amber, Myanmar: V. espinosus Hedenäs, Heinrichs \& A.R. Schmidt (2014: 8), V. longiacuminatus Hedenäs, Heinrichs \& A.R. Schmidt (2014: 7), V. oblongus Hedenäs, Heinrichs \& A.R. Schmidt (2014: 6), and V. pyrrhobryoides N. E. Bell (2007: 518). All have narrow lanceolate leaves, a percurrent costa and subquadrate laminal cells, and are thus referred to Hypnodendrales.

\subsection{Class/superorder level}

!!*** Krassiloviella Shelton, Stockey, Rothwell \& Tomescu (2016: 693), with one species, K. limbelloides Shelton, Stockey, Rothwell \& Tomescu (2016: 693), from Lower Cretaceous of Canada (Vancouver Island), was referred to the family Tricostaceae (class Bryopsida, subclass Bryidae, superorder Hypnanae, order level incertae sedis), described for the genus Tricosta from the same deposits. Like in Tricosta, the leaves are tricostate, but Krassiloviella differs by more delicate, erect, concave leaves up to $5 \mathrm{~mm}$ long, with wider and thicker costae converging in the apex; laminal cells are mostly isodiametric; and rhizoids at leaf base both abaxial and adaxial.

!!*** Palaeodichelyma Ignatov \& Shcherbakov (2007: 327) with one species, P. sinitzae Ignatov \& Shcherbakov (2007: 327), from three localities in Russia, Transbaikalia (first and second: Upper Jurassic or Lower Cretaceous; third: Lower Cretaceous). Short branches that are either juvenile vegetative branches or inflorescences indicate its 
pleurocarpous affinity (superorder Hypnanae). The moss has costate leaves, elongate-rectangular laminal cells and short branches.

!!*** Tricosta Shelton, Stockey, Rothwell \& Tomescu (2015: 1886), with one species, T. plicata Shelton, Stockey, Rothwell \& Tomescu (2015: 1886), from Lower Cretaceous of Canada (Vancouver Island). Excellent preservation allowed the authors a complete reconstruction of a fossil moss gametophyte, including gametangia and details of branch primordia, which place them to Superorder Hypnanae, without placement in any definite order. The genus Tricosta was segregated in a separate family Tricostaceae (class Bryopsida, subclass Bryidae, superorder Hypnanae, order level incertae sedis), that is characterized by three stout costae up to 0.9 leaf length, and mostly rhombic mid-leaf cells and elongate, to 5:1, basal leaf cells.

\subsection{Division level}

!**** Baigulia Ignatov, Karasev \& Sinitsa (2011: 53), with one species, B. complanata Ignatov, Karasev \& Sinitsa (2011: 61), from Upper Jurassic of Transbaikalia, Russia, is a large, branched plant with ecostate, unbordered leaves to $5 \mathrm{~mm}$ long, and with rectangular laminal cells. Cell structure is against its pleurocarpous affinity and resembles the sympatric genus Bryokhutuliinia, which, however, differs by bordered leaves.

!**** Baiguliella Ignatov, Karasev \& Sinitsa (2011: 63), with only B. minuta Ignatov, Karasev \& Sinitsa (2011: 63), from Upper Jurassic of Transbaikalia, Russia, is a small plant with remotely arranged linear-lanceolate leaves spreading at about $90^{\circ}$ angle; costa absent or weak and indistinct; laminal cells narrowly linear.

!**** Bryiidites Barclay, Duckett, McElwain, van Es, Mostaert, Pressel \& Sageman (2013: 2453), with one species, $B$. utahensis Barclay, Duckett, McElwain, van Es, Mostaert, Pressel \& Sageman (2013: 2453), from Middle Cretaceous of USA (Utah). Filaments on leaf surface, considered to represent an epiphyllous moss.

!**** Bryokhutuliinia Ignatov (1992: 379) includes four species (overview in Mamontov \& Ignatov 2019): $B$. jurassica Ignatov (1992: 379), Upper Jurassic or Lower Cretaceous, Mongolia; B. crassimarginata Ignatov, Karasev, Sinitsa \& Maslova (2013: 70), Middle or Upper Jurassic, Transbaikalia, Russia; B. ingodensis (Srebrodolskaya [1980: 27]) Ignatov (1992: 385), Upper Jurassic or Lower Cretaceous, Transbaikalia, (also Ignatov et al. 2011); B. obtusifolia Ignatov \& Shcherbakov (2011a: 20), Lower Cretaceous, Transbaikalia. All of them consist of large plants with stems irregularly to regularly pinnately branched, rather loosely terete to complanate foliate. Leaves ovate-oblong to ovatelanceolate, broadly rounded above or gradually tapered to the blunt apex, costa absent, limbidium distinct all around the leaf, lamina cells rectangular, border cells linear, thick-walled. Sporophytes on short lateral branches. Capsules immersed to slightly emergent, ovate, with conic operculum. A position of Bryokhutuliinia in the Dicranidae was considered most likely (Mamontov \& Ignatov 2019), although affinity to pleurocarpous mosses in the Superorder Hypnanae is only a little less likely.

!**** Heinrichsiella Bippus, Savoretti, Escapa, García Massini \& Guido (2019: 884), with one species, H. patagonica Bippus, Savoretti, Escapa, García Massini \& Guido (2019: 884), from Jurassic of Argentina, possesses features of Polytrichaceae or Timmiellaceae.

!**** Mnioites X.-W. Wu, X.-Y. Wu \& Y.-D. Wang (2000: 170), with one species, M. brachyphylloides X.-W. Wu, X.-Y. Wu \& Y.-D. Wang (2000: 170), from Lower Jurassic of Xinjang, China, has broadly ovate leaves, resembling extant Mnium Hedw., although without sufficient details for certain placement in Bryidae.

!**** Moss gametophytes \#1-2 Drinnan \& Chambers (1986) from Lower Cretaceous of SE Australia do not provide enough details, one of them is more or less similar by habit to Orthotrichaceae.

!**** Muscites antarcticus Cantrill (2000: 158) from Lower Cretaceous of Snow Island, Antarctica is represented by numerous imprints, without apparent cellular structure.

!**** Muscites cretaceus Ettingshausen \& Debey (1859: 185), from Cretaceous of Germany, small fragment of shoot with costate, lanceolate leaves.

!**** Muscites drepanophyllus S.Q. Wu (1999: 9) from Upper Jurassic or Lower Cretaceous of China, has an erect stem to $3 \mathrm{~cm}$ high, with an acrocarpous habit due to branches divergent at acute angle; leaves are erect at base, gradually reflexed in the middle, to $4 \mathrm{~mm}$ long and $0.8 \mathrm{~mm}$ wide, oblong, obtuse at apex; in some leaves the costa can be interpreted as broad and then the plant can be compared with Oligotrichum DC. (Polytrichaceae). However, abundant branching alternatively suggests aquatic Dicranidae, e.g. Scouleria Hook. or Dialytrichia (Schimp.) Limpr. !**** Muscites fontinalioides Krassilov (1973), from Upper Jurassic of the Russian Far East (Bureya River), has stem with leaf fragments and a sessile ovoid capsule, ca. $0.5 \mathrm{~mm}$ long, which is shorter than what is usual in Fontinalis Hedw.

!**** Muscites gracilis Mays \& Cantrill in Mays et al. (2015: 1047), Late Cretaceous of Chatham Islands (east of New Zealand), was left without class assignment, but Fig. 5D shows a stem terminating in which seems a wide, plate-like 
perigonium with several subterminal innovations, somewhat similar to those in Philonotis Brid. or Bryum Hedw.; thus we suggest its affinity to Bryidae, as in Dicranidae such branching is less common.

!**** Muscites kujiensis T. Katagiri in Katagiri et al. (2013:297) from Upper Cretaceous amber of Japan, has small leaves with strong costa and large isodiametric cells, and attenuate leafless stem apices.

!**** Muscites ostracodiferus Krassilov (1982: 6), from Lower Cretaceous of Mongolia. Aquatic moss with branched stem, remotely arranged leaves to $6 \mathrm{~mm}$ long, with a long single costa.

!**** Muscites samchakianus Srebrodolskaya (1980: 28), from Upper Jurassic of Transbaikalia, Russia, somewhat similar to Bryokhutuliinia from about the same age and regions, but twice as small. Costa absent, cells indiscernible. !**** Muscites tenellus S.Q. Wu (1999: 9), from Upper Jurassic or Lower Cretaceous of China, has erect stem 3-4 cm high, with filiform leaves to $3 \mathrm{~mm}$ long, similar to some Dicranidae, e.g. Flexitrichum Ignatov \& Fedosov, or Bryidae, e.g. Bartramia Schwägr.

!**** Muscites sp. Passalia (2007: 567), from Upper Cretaceous of Argentina, is a large moss with loosely arranged, broadly oblong leaves, $1.4-2,5 \mathrm{~mm}$ long $\times 0,8-1,2 \mathrm{~mm}$ wide, with a strong costa. It may relate to Bryidae (e.g. Mniaceae or Bryaceae) or Dicranidae (e.g. Scouleriaceae).

!**** Muscites sp. Puebla, Mego \& Prámparo (2012: 226), from Lower Cretaceous of Argentina, comprises imprints of narrowly lanceolate leaves near the ovate capsule that is open and shows more or less apparent, incompletely preserved (ca. 16?) peristome teeth. Plants were compared with Hypnodontopsis Z. Iwats. \& Nog., a common moss in Eocene amber, but its placement in Dicranidae seems to be the most likely option.

!**** Muscites sp. 1-3 Ignatov \& Shcherbakov (2011a), from Lower Cretaceous of Transbaikalia, Russia, are mosses with narrow appressed leaves, most similar to Dicranales, without apparent cellular structure.

!**** Ningchengia Heinrichs, X. Wang, Ignatov \& M. Krings (2014b: 51), with one species, N. jurassica Heinrichs, X. Wang, Ignatov \& M. Krings (2014b: 51), from Upper Jurassic of China, is a tuft with several cylindrical capsules on long setae; leaves are lanceolate with long single costa. Although the gross morphology suggests an affinity with Pottiaceae, Ditrichaceae, Dicranaceae or Rhabdoweisiaceae, its position in other families, including nematodontous Tetraphidopsida and Polytrichopsida, cannot be ruled out.

!**** Stachybryolites X.-W. Wu, X.-Y. Wu \& Y.-D. Wang (2000: 168), with only S. zhoui X.-W. Wu, X.-Y. Wu \& Y.-D. Wang (2000: 169), from Lower Jurassic of China, Xinjang, has a habit of extant Campylopus or other large Dicranaceae s. 1., with crowded, narrow leaves and proximal parts of plants almost leafless.

!**** Taimyrobryum Ignatov, Heinrichs, Schäfer-Verwimp \& Perkovsky (2016b: 26), with one species, $T$. martynoviorum Ignatov, Heinrichs, Schäfer-Verwimp \& Perkovsky (2016b: 26), from Upper Cretaceous amber of North Siberia, is one shoot, resembling Archidium Brid. in habit, although the cell pattern allows pleurocarpous affinities as well.

!**** Tricostium Krassilov (1973: 100) was described for one species, T. papillosum Krassilov (1973: 100) from Upper Jurassic or Lower Cretaceous deposits of Russian Far East (Bureya River), later referred to Jurassic (Krassilov \& Schuster, 1984) for leaves from bulk maceration, which in addition to a strong median costa have intramarginal costae to $0.5-0.9$ leaf length; leaves of 1.2-1.8 mm long $\times 0.5-1.3 \mathrm{~mm}$ wide, cells $15-18 \mu \mathrm{m}$ wide, polygonal to short rectangular, with 8-10 small papillae. Lower Cretaceous compressions from Transbaikalia include T. longifolium Ignatov \& Shcherbakov (2011a: 34), represented by separate leaves and foliate shoots, with similar laminal cells and costae, but longer (4-6 $\mathrm{mm}$ ) leaves; cell papillosity could not be discerned in compressions. Tricostium triassicus Ignatov \& Shcherbakov from Lower Triassic of Yaman-Us in Mongolia was described based on one incompletely preserved leaf, which is similar to T. longifolium in shape and dimensions, but the intramarginal costae are weaker.

!**** Yorekiella Krassilov (1973: 101), with one species, Y. pusilla Krassilov (1973: 101), from Lower Cretaceous of Russian Far East (Bureya), has shoots with leaves 0.2-0.4 mm only, terete to complanate, leaves acute, unbordered, ecostate, cells isodiametric.

8. Paleocene and Eocene. Tomescu et al. (2018) listed 102 mosses from the Eocene and two from the Paleocene. Most of them are amber inclusions. Comments on all of them would be only moderately informative, as many taxa that look rather similar to extant genera could also be placed in other genera and often, also to other families. For this reason, some authors published such fossils under "Moss pleurocarpous \#xxx" or under the name of a superficially similar moss genus with suffix '-ites'. However, the names of extant genera and even species are also used in about the same situation. In most cases such an "identification" means that there are no characters that would contradict such a placement, but they do not exclude other alternative placements either. To facilitate the overview, Eocene taxa are ranked here into four groups by the level of similarity to extant taxa. 
8.1. Mosses with a combination of traits that is unknown in extant genera. Such mosses are common in Paleozoic and Mesozoic, but in Cenozoic there is only one: Pottiodicranum papillosum Ignatov, Schäfer-Verwimp, Perkovsky \& Heinrichs (2016c: 234), from Ukraine.

8.2. Mosses that can be placed in an extant genus are as follows:

\begin{tabular}{|c|c|}
\hline Genus & Reference \\
\hline Aptychella (Broth.) Herzog & Frahm, 2004a, 2010 \\
\hline Atrichum P. Beauv. & Frahm, 2004a, 2004b, 2010 \\
\hline Arrhenopterum Hedw. (as Aulacomnium heterostichoides & Janssens et al., 1979 \\
\hline \multicolumn{2}{|l|}{ Janssens, D.G. Horton \& Basinger) } \\
\hline Brothera Müll. Hal. & Frahm \& Gröhn, 2013 \\
\hline Calliergon (Sull.) Kindb. & Kuc, $1973 b$ \\
\hline Campylopodiella Cardo $t$ & Frahm, 2004a, 2010 \\
\hline Campylopus Brid. & Frahm, 2004a, 2010 \\
\hline Cynodontium Bruch \& Schimp. & Ignatov et al., 2016a \\
\hline Ephemeropsis K.I. Goebel & Köck, 1939 \\
\hline Fabronia Raddi & Weitschat \&Wichard, 2002; Frahm, 2010 \\
\hline Grimmia Hedw. & Frahm \& Gröhn, 2013 \\
\hline Haplocladium (Müll. Hal.) Müll. Hal. & Frahm, 2004a, 2010 \\
\hline Herpetineuron (Müll. Hal.) Cardot & Grimaldi et al. 2018 Fig. 4F \\
\hline Hypnodontopsis Z. Iwats. \& Nog. & Frahm, 2004a, 2010; Ignatov \& Perkovsky, 2011, 2013a \\
\hline Isopterygium Mitt. & Ignatov \& Perkovsky, 2011 \\
\hline Pyrrhobryum Mitt. & Frahm, 2010; Heinrichs et al., 2014a \\
\hline $\begin{array}{l}\text { Sarmentypnum Tuomik. \& T.J. Kop. (as Drepanocladus cf. } \\
\text { exannulatus (Schimp.) Warnst.) }\end{array}$ & Kuc, $1973 b$ \\
\hline Sphagnum L. & $\begin{array}{l}\text { Frahm, 2010; Ignatov et al., 2019; Kuc, 1973b; Riegel \& Wilde } \\
2016\end{array}$ \\
\hline Trachycystis Lindb. & Frahm, 2004a, 2010; Ignatov \& Perkovsky, 2013a \\
\hline
\end{tabular}

8.3. Mosses which could be places to an extant family are as follows:

\begin{tabular}{ll}
\hline Family & Species, Reference \\
\hline Mniaceae & Rhizomnium dentatum Heinrichs, Hedenäs, Schäf.-Verw., Feldberg \& A.R. Schmidt (2014a: 114) \\
Neckeraceae & Grimaldi et al. 2018 Fig. 4D-E; Neckerites pusillus Ignatov \& Perkovsky (2011: 7) \\
Polytrichaceae & Polytrichites pogonatoides Frahm (2010: 23). \\
\hline
\end{tabular}

8.4. Many specimens of the order Hypnales from Eocene amber faced difficulties in identification up to even family level. Recent molecular phylogenetic revisions resulted in species referred in mid-20th century to the genus Drepanocladus (Müll. Hal.) G. Roth now being classified in three families, and species of Hypnum Hedw. in eight families (Kučera et al. 2019; Hodgetts et al. 2020). For most Hypnum-like fossil mosses, it would be difficult to choose the family in their current narrow circumscriptions.

It is highly likely that the European Eocene amber inclusions represent (in addition to families mentioned above) Sematophyllaceae, Pylaisiadelphaceae, Hypnaceae, Pylaisiaceae, Amblystegiaceae, Brachytheciaceae, Meteoriaceae, Leskeaceae, and Myuriaceae. However, all these records may be challenged by detailed evaluations, and for the same reason we do not recommend use for calibration purposes genera such as e.g. Hypnum, Ctenidium (Schimp.) Mitt., or Palamocladium Müll. Hal. Likewise, other Eocene records form North America (Britton 1899, Brown 1962, Kuc 1972, 1974, Wittlake 1968), and from Asia (Ignatov \& Perkovsky 2013b, Heinrichs et al. 2016) cannot also be assigned to any family with certainty. It is noteworthy, however, that most of them have an undoubtful pleurocarpous habit, while mosses of Dicranales morphology are relatively few, e.g. Ditrichites Kuc (1974: 411). The latter cannot be identified to family after parts of Ditrichum Timm ex Hampe were segregated not only into different genera, but even different families (Fedosov et al. 2016). 
9. Oligocene to Pleistocene. Comprehensive reviews of Late Tertiary and Quaternary bryophytes were published by Miller $(1980,1984)$. and Miocene records were summarized by Tomescu et al. (2018). However, numerous postEocene moss records remain scattered. They are often included in publications that describe whole fossil floras, where mosses are represented by few specimens, often referred to form genera. Their compilation requires a special effort.

There are relatively few publications with illustrations detailed enough for species identification, such as the Late Miocene or Pliocene Beaufort formation bryophytes described by Kuc (1973a). More often illustrations, if available at all, allow alternative interpretations of the represented fossils, and using those names for calibration is dangerous.

Exceptionally excellent preservations, allowing reliable species identification, occur in Dominican amber (Frahm, 1993, 1996, 2001, 2004c, 2008, Frahm \& Newton 2005). Many such fossils were identified up to species level, and the provided illustrations leave no doubt in this case. A note of caution with Dominican amber, however, is briefly discussed by Frahm \& Newton (2005), as some amber moss specimens may represent extant mosses embedded in copal or even forgeries. To be certain of the age of Dominican amber inclusions, a specimen has to be checked with FTIR spectroscopy. A proper example of such study was Heinrichs et al. (2013), which confirmed the Miocene age with the extant and sympatric Macromitrium richardii Schwägr. (1826: 70).

\section{General comments}

Well-preserved Late Tertiary mosses can in many cases be referred to extant species. The selection of genera for calibration has to be done with caution, considering the reliability of the identification and not by just using the published names. The complete preservation of mosses in Miocene Dominican amber makes those inclusions prime candidates for phylogenetic tree calibrations.

Eocene mosses are well-represented in amber, comprising mainly subtropical or south-temperate mosses, with prevalence of pleurocarps. Small fragments sizes in most cases preclude their placement into a single family: a specimen may be referred to two or few different families. Nevertheless, 19 extant genera may be recognized in Eocene collections: Aptychella, Atrichum, Arrhenopterum, Brothera, Calliergon, Campylopodiella, Campylopus, Cynodontium, Ephemeropsis, Grimmia, Haplocladium, Herpetineuron, Hypnodontopsis, Isopterygium, Pyrrhobryum, Sarmentypnum, Sphagnum, and Trachycystis. Families that are likely represented in Eocene fossils include Amblystegiaceae, Aulacomniaceae, Brachytheciaceae, Dicranaceae s.l. (incl. Rhabdoweisiaceae), Grimmiaceae, Hypnaceae, Pylaisiaceae, Leskeaceae, Meteoriaceae, Mniaceae, Myuriaceae, Neckeraceae, Polytrichaceae, Sematophyllaceae s.l., and Sphagnaceae. Eocene mosses almost always fit the combination of traits that is known in extant genera, with probably only two exceptions: the genus Pottiodicranum and Rhizomnium dentatum, which still can be referred to extant order Dicranales and extant family Mniaceae, respectively.

Some Cretaceous fossils can be placed into extant genera (Campylopodium, Cynodontium, Sphagnum), while other fossils show combinations of characters unusual for extant genera. Some of them could be placed in existing families, e.g. Eopolytrichum in Polytrichaceae; while for Tricosta and Krasiloviella a new family, Tricostaceae, was established within the superorder Hypnanae. In the case of Bryokhutuliinia, the combination of characters is drastically different, precluding placement at even subclass level: most its traits are in favor of Dicranidae, but the placement in Bryidae is only slightly less probable (Mamontov \& Ignatov 2019). Upper and mid-Jurassic fossils are similar to Cretaceous ones. The mid-Mesozoic seems to be a time when pleurocarpous mosses appeared (Shelton et al. 2015, 2016), although acrocarpous records prevail until the Eocene. Therefore, this important event in moss evolution probably happened in approximately the same time as for ferns (Schneider et al. 2004) and hepatics (Wilson et al. 2007, Heinrichs et al. 2007, Villarreal et al. 2016), coinciding with angiosperms spreading and diversification on the Earth, i.e. the Cretaceous Terrestrial Revolution. Triassic mosses are few, and their placement in extant groups is uncertain.

Permian is the oldest period when fossil mosses are numerous. Half of them (especially those known from the Angaraland) belong to protosphagnalean groups, while the morphology of the other half does not contradict placement in extant classes / subclasses. In most cases Permian fossils cannot be placed in a single class or subclass, as their structure bears not enough characters for a definite choice among several possibilities. Accumulated data support the conclusion of Schuster \& Krassilov (1984) that Paleozoic mosses were much more numerous in the temperate (Angaraland and Gondwana) than in the tropical or subtropical realms (Euramerica). Protosphagnalean mosses have many characters unknown in other mosses, both extant and fossil, and have to be considered as an extinct lineage. 
Unequivocal mosses are known since Upper Carboniferous, but their structure does not help to attribute any of them to a definite class of extant mosses. Lower Carboniferous remains may belong to mosses, but proof of their identity is still needed. Pre-Carboniferous records are awaiting proof of either age of fossils or their identity as mosses at all.

Extensive search in the last two or three decades contributed no less than half of all records to the current knowledge; thus new findings in the near future may greatly improve our knowledge of moss evolution.

\section{Author contributions}

The section on Protosphagnalean mosses is written and illustrated by MI and EM, the rest of review is done by MI, who is the only responsible for mistakes.

\section{Acknowledgements}

We are grateful for critical comments to Alexander Bippus, and also indebted to him for English correction of the early version of the manuscript. The work was partly supported by RFBR 19-04-00976.

\section{References}

Amaral, P.G.C., Bernardes de Oliveira, M., Ricardi-Branco, F. \& Broutin, J. (2004) Presencia de Bryopsida fértil en los niveles Westfalianos del subgrup Itararé, Cuenca de Paraná, Brasil. Tropical Bryology 25: 101-110.

https://doi.org/10.11646/bde.25.1.12

Anderson, J.M. \& Anderson, H.M. (1985) Palaeoflora of South Africa. Prodromus of South African Megafloras, Devonian to Lower Cretaceous. A.A. Balkema, Rotterdam, 423 pp.

Arnold, C.A. (1932) Microfossils from Greenland coal. Papers of the Michigan Academy of Science, Arts and Letters 15: 51-61.

Barclay, R.S., McElwain, J.C., Duckett, J., Es, A.S., van, Mostaert, M.H., Pressel, S. \& Sageman, B.B. (2013) New methods reveal oldest known fossil epiphyllous moss: Bryiidites utahensis gen. et sp. nov. (Bryidae). American Journal of Botany 100 (12): $2450-2457$. https://doi.org/10.3732/ajb.1300209

Bell, N.E. \& York, P.V. (2007) Vetiplanaxis pyrrhobryoides, a new fossil moss genus and species from Middle Cretaceous Burmese amber. The Bryologist 110 (3): 514-520. https://doi.org/10.1639/0007-2745(2007)110[514:VPANFM]2.0.CO;2

Bescherelle, É. (1873) Florule bryologique de la Nouvelle-Calédonie. Annales des Sciences Naturelles; Botanique sér. 5 18: 184-245. Bippus, A., Stockey, R.A., Rothwell, G.W. \& Tomescu, A.M.F. (2017) Extending the fossil record of Polytrichaceae: Early Cretaceous Meantoinea alophosioides gen. et sp. nov., permineralized gametophytes with gemma cups from Vancouver Island. American Journal of Botany 104: 584-597.

https://doi.org/10.3732/ajb.1700002

Bippus, A.C., Escapa, I.H. \& Tomescu, A.M.F. (2018) Wanted dead or alive (probably dead): Stem group Polytrichaceae. American Journal of Botany 105 (8): 1243-1263. https://doi.org/10.1002/ajb2.1096

Bippus, A.C., Savoretti, A., Escapa, I.H., García Massini, J.L. \& Guido, D. (2019) Heinrichsiella patagonica gen. et sp. nov.: a permineralized acrocarpous moss from the Jurassic of Patagonia. International Journal of Plant Sciences 180 (8): $882-891$. https://doi.org/10.1086/704832

Bippus, A., Rothwell, G.W. \& Stockey, R.A. (2021) Cynodontium luthii sp. nov. a permineralized moss gametophyte from the Late Cretaceous of the North Slope of Alaska. American Journal of Botany 108 (3): 1-10.

https://doi.org/10.1002/ajb2.1617

Bomfleur, B. \& Kerp, H. (2010) Dicroidium diversity in the Upper Triassic of North Victoria Land, East Antarctica. Review of Palaeobotany and Palynology 160: 67-101. https://doi.org/10.1016/j.revpalbo.2010.02.006

Bomfleur, B., Klymiuk, A.A., Taylor, E.L., Taylor, T.N., Gulbranson, E.L. \& Isbell, J.L. (2014) Diverse bryophyte mesofossils from theTriassic of Antarctica. Lethaia 47: 120-132. 
https://doi.org/10.1111/let.12044

Boulter, M. (1994) An approach to a standard terminology for palynodebris. In: Traverse, A. (Ed.) Sedimentation of Organic Particles. Cambridge University Press, Cambridge, pp. 199-216.

https://doi.org/10.1017/CBO9780511524875.012

Britton, E.G. (1899) A new Tertiary fossil moss. Bulletin of the Torrey Botanical Club 26: 79-81. https://doi.org/10.2307/2478308

Brown, J.T. \& Robison, C.R. (1974) Diettertia montanensis, gen. et sp. nov., a fossil moss from the Lower Cretaceous Kootenai Formation of Montana. Botanical Gazette 135: 170-173.

https://doi.org/10.1086/336747

Brown, R.W. (1962) Paleocene flora of the Rocky Mountains and Great Plains. U.S. Geological Survey Professional Paper $375:$ 1-119. +69 pls. https://doi.org/10.3133/pp375

Busche, R. von (1968) Als Laubmossreste gedeutete Pflanzenfossilien aus den Lebacher Schichten (Autunien) von St. Wendel, Saar. Argumenta Palaeobotanica 2: 1-14.

Cantrill, D.J. (2000) A Cretaceous (Aptian) flora from President Head, Snow Island, Antarctica Palaeontographica, Abteilung B 253: 153-191.

https://doi.org/10.1127/palb/253/2000/153

Cardona-Correa, C., Piotrowski, M.J., Knack, J.J., Kodner, R.B., Geary, D.H. \& Graham, L.E. (2016) Peat moss-like vegetative remains from Ordovician carbonates. International Journal of Plant Sciences 177: 523-538.

https://doi.org/10.1086/686242

Chandra, S. (1995) Bryophytic remains from the early Permian sediments of India. The Palaeobotanist 43 (2) 16-48.

Christiano de Souza, I.C., Ricardi Branco, F.S. \& Leon Vargas, Y. (2012) Permian bryophytes of western Gondwanaland from the Parana Basin in Brasil. Palaeontology 55 (1): 229-241.

https://doi.org/10.1111/j.1475-4983.2011.01111.x

Dixon, H.N. (1932) Classification of mosses. In: Verdoorn, F. (Ed.) Manual of Bryology. The Hague: Martinus Nijhoff, pp. $397-412$.

Dozy, F. \& Molkenboer, J.H. (1846) Musci Frondosi Inediti Archipelagi Indici 2. H. W. Hazenberg, Lugduni-Batavorum, pp. 25-51, pl. $11-20$.

Drinnan, A.N. \& Chambers, T.C. (1986) Flora of the Lower Cretaceous Koonwarra Fossil Bed (Korumburra Group), South Gippsland, Victoria. Memoir of the Association of Australasian Palaeontologists 3: 1-77.

Durante, M.V. (1976) Paleobotanical foundation of the Carboniferous and Permian stratigraphy of Mongolia. Nauka, Moscow, 279 pp. [In Russian]

Ettingshausen, C. von \& Debey, M.H. (1859) Die Unweltlichen Acrobryen des Kreidegebirges von Aachen und Maestricht, 150 (17). Denkschriften, Akademie der Wissenschaften in Wien.

Fedosov, V.E., Fedorova, A.V., Fedosov, A.E. \& Ignatov, M.S. (2016) Phylogenetic inference and peristome evolution in haplolepideous mosses, focusing on Pseudoditrichaceae and Ditrichaceae s. 1. Botanical Journal of the Linnean Society 181 (2): 139-155. https://doi.org/10.1111/boj.12408

Fefilova, L.A. (1973) [New Permian mosses from northern Pre-Ural Depression]. Geologija i Poleznye Iskopaemye Severo-Vostoka Evropejskoj Chasti SSSR. 1972. Syktyvkar, Akademija Nauk SSSR: 85-91, 2 pl. [In Russian]

Fefilova, L.A. (1978) Permian mosses of European North of USSR [Listostebelnye mkhi permi Evropeiskogo Severa SSSR] Nauka, Leningrad, 120 pp. [In Russian]

Frahm, J.-P. (1993) Mosses in Dominican amber. Journal of the Hattori Botanical Laboratory 74: 249-259.

Frahm, J.-P. (1996) New records of fossil mosses from Dominican amber. Cryptogamie, Bryologie, Lichénologie 17: $231-236$.

Frahm, J.-P. (2001) New records of mosses from Dominican amber. Tropical Bryology 20: 39-42. https://doi.org/10.11646/bde.20.1.6

Frahm, J.-P. (2004a) A new contribution to the moss flora of Baltic and Saxon amber. Review of Palaeobotany and Palynology 129: 81-101. https://doi.org/10.1016/j.revpalbo.2003.11.004

Frahm, J.-P. (2004b) Atrichum (Musci, Polytrichaceae) in Baltic amber. Journal of the Hattori Botanical Laboratory 95: $219-227$.

Frahm, J.-P. (2004c). New records of mosses from Dominican amber. Tropical Bryology 25: 25-27. https://doi.org/10.11646/bde.25.1.5

Frahm, J.-P. (2008) Eohypopterygiopsis dominicensis, a new genus and species, and Pyrrhobryum spiniforme from the Miocene of the Dominican Republic. Tropical Bryology 29: 48-50. https://doi.org/10.11646/bde.29.1.6

Frahm, J.-P. (2009) The first record of a Sphagnum from the Tertiary in Baltic Amber and other new records of mosses from Baltic and 
Dominican amber. Cryptogamie, Bryologie 30: 259-263.

Frahm, J.-P. (2010) Die Laubmoosflora des Baltischen Bernsteinwaldes. Weissdorn-Verlag, Jena, 101 pp.

Frahm, J.-P. \& Gröhn, C. (2013) More fossil bryophytes from Baltic amber. Archive for Bryology 159: 1-9.

Frahm, J.-P. \& Newton, A.E. (2005) A new contribution to the moss flora of Dominican amber. The Bryologist 108: 526-536. https://doi.org/10.1639/0007-2745(2005)108[0526:ANCTTM]2.0.CO;2

Frey, W. (1970) Blattenwicklung bei Laubmoosen. Nova Hedwigia 20: 463-556.

Frey, W. \& Stech, M. (2009) Bryophyta (Musci, mosses). In: Frey, W. (Ed.) Syllabus of plant families A. Engler's Syllabus der Pflanzenfamilien. Part 3. Bryophytes and seedless vascular plants. 13th ed. Gebr. Borntraeger Verlagsbuchhandlung, Stuttgart, Germany, pp. 116-257.

Goffinet, B., Buck, W.R. \& Shaw, A.J. (2009) Morphology, anatomy, and classification of the Bryophyta. In: Goffinet, B. \& Shaw, A.J. (Eds.) Bryophyte biology, 2nd edn. Cambridge University Press, Cambridge, pp. 55-138.

Goffinet, B. \& Buck, W.R. (2004) Systematics of the Bryophyta (mosses): from molecules to a revised classification. In: Goffinet, B., Hollowell, V. \& Magill, R. (Eds.) Molecular systematics of Bryophytes. Missouri Bot. Garden Press, St.-Louis, pp. $205-239$.

Gomankov, A.V. (2020) Peculiar lycopsids from Yaman-Us locality (the Upper Permian of the Southern Mongolia). Lethaea Rossica 20: 34-43. [In Russian, English summary] [http://paleobot.ru/pdf/03_2020_20.pdf]

Gomankov, A.V. \& Meyen, S.V. (1986) Tatarina flora (composition and distribution in the Late Permian of Eurasia) [Tatarinovaya flora (sostav i rasprostranenie v pozdnej permi Evrasii)]. Trudy Geologicheskogo Instituta Akademii Nauk SSSR 401: 1-174. [In Russian]

Gottsche, C.M., Lindenberg, J.B.G. \& Nees ab Esenbeck, C.G. (1846) Synopsis Hepaticarum. Fasc. IV. Meissner, Hamburg, pp. 465624.

Grimaldi, D.A., Sunderlin, D., Aaroe, G.A., Dempsky, M.R., Parker, N.E., Tillery, G.Q., White, J.G., Barden, P. Nascimbene, P.C. \& Williams, C.J. (2018) Biological Inclusions in Amber from the Paleogene Chickaloon Formation of Alaska. American Museum Novitates 3908: 1-37. https://doi.org/10.1206/3908.1

Hampe, E. (1839) Relation über die von dem Reisenden C. Beyrich auf seiner letzten Reise in Nordamerika gesammelten Laubmoose. Linnaea 13: 39-48.

Hattori, S. \& Inoue, H. (1958) Preliminary report on Takakia lepidozioides. Journal of the Hattori Botanical Laboratory 18: $133-137$.

Hedenäs, L., Heinrichs, J. \& Schmidt, A.R. (2014) Bryophytes of the Burmese amber forest: amending and expanding the circumscription of the Cretaceous moss genus Vetiplanaxis. Review of Palaeobotany and Palynology 209: 1-10. https://doi.org/10.1016/j.revpalbo.2014.05.008

Hedwig, J. (1801) Species Muscorum Frondosorum. Leipzig, 352 pp.

Heinrichs, J., Hentschel, J., Wilson, R., Feldberg, K. \& Schneider, H. (2007) Evolution of leafy liverworts (Jungermanniidae, Marchantiophyta): estimating divergence times from chloroplast DNA sequences using penalized likelihood with integrated fossil evidence. Taxon 56: 31-44. https://doi.org/10.2307/25065908

Heinrichs, J., Vitt, D.H., Schäfer-Verwimp, A., Ragazzi, E., Marzaro, G., Grimaldi, D.A., Nascimbene, P.C., Feldberg, K. \& Schmidt, A.R. (2013) The moss Macromitrium richardii (Orthotrichaceae) with sporophyte and calyptra enclosed in Hymenaea resin from the Dominican Republic. Polish Botanical Journal 58 (1): 221-230. https://doi.org/10.2478/pbj-2013-0022

Heinrichs, J., Hedenäs, L., Schäfer-Verwimp, A., Feldberg, K. \& Schmidt, A.R. (2014a) An in situ preserved moss community in Eocene Baltic amber. Review of Palaeobotany and Palynology 210: 113-118. https://doi.org/10.1016/j.revpalbo.2014.08.005

Heinrichs, J., Wang, X., Ignatov, M.S. \& Krings, M. (2014b) A Jurassic moss from Northeast China with preserved sporophytes. Review of Palaeobotany and Palynology 204: 50-55. https://doi.org/10.1016/j.revpalbo.2014.02.005

Heinrichs, J., Schäfer-Verwimp, A., Hedenäs, L., Ignatov, M.S. \& Schmidt, A.R. (2014c) An acrocarpous moss in Cretaceous amber from Myanmar. Cretaceous Research 51: 260-265. https://doi.org/10.1016/j.cretres.2014.06.010

Heinrichs, J., Scheben, A., Bechteler, J., Lee, E., Schäfer-Verwimp, A., Hedenäs, L., Singh, H., Pócs, T., Nascimbene, P.C., Peralta, D.F., Renner, M. \& Schmidt, A.R. (2016) Crown group Lejeuneaceae and pleurocarpous mosses in early Eocene (Ypresian) Indian amber. PLOS ONE 11 (5): e0156301. https://doi.org/10.1371/journal.pone.0156301

Hodgetts, N.G., Söderström, L., Blockeel, T.L., Caspari, S., Ignatov, M.S., Konstantinova, N.A., Lockhart, N., Papp, B., Schröck, C., SimSim, M., Bell, D., Bell, N., Blom, H.H., Bruggeman-Nannenga, M.A., Brugués, M., Enroth, J., Flatberg, K.I., Garilleti, R., Hedenäs, 
L., Holyoak, D.T., Hugonnot, V., Kariyawasam, I.U., Köckinger, H., Kučera, J., Lara, F. \& Porley, R.D. (2020) An annotated checklist of bryophytes of Europe, Macaronesia and Cyprus. Journal of Bryology 42 (1): 1-116.

https://doi.org/10.1080/03736687.2019.1694329

Hooker, W.J. (1816) Some account on Tayloria splachnoides, a new moss allied to the genus Splachnum. Journal of Science and the Arts 2 (3): 144-147.

Hübers, M. \& Kerp, H. (2012) Oldest known mosses discovered in Mississippian (late Visean) strata of Germany. Geology 40: 755-758. https://doi.org/10.1130/G33122.1

Hübers, M., Kerp, H., Schneider, J.W. \& Gaitzsch, B. (2013) Dispersed plant mesofossils from the Middle Mississippian of eastern Germany: bryophytes, pteridophytes and gymnosperms. Review of Palaeobotany and Palynology 193: 38-56.

https://doi.org/10.1016/j.revpalbo.2013.01.006

Ignatov, M.S. (1990) Upper Permian mosses from the Russia Platform. Palaeontographica Abteilung B, 217: 147-189 + Pl. 1-9.

Ignatov, M.S. (1992) Bryokhutuliinia jurassica, gen. et spec. nova, a remarkable fossil moss from Mongolia. Journal of the Hattori Botanical Laboratory 71: 377-388.

Ignatov, M.S. (2013) Mosses of Paleozoic and Mesozoic. Lethaea rossica, Suppl. 1: 29-40. [http://paleobot.ru/pdf/06_suppl_2013.pdf]

Ignatov, M.S., Abakarova, A.S., Alekseev, P.I. \& Kučera, J. (2016a) Cynodontium eocenicum, a new moss from the Baltic Amber. Arctoa 25 (2): 236-240.

https://doi.org/10.15298/arctoa.25.19

Ignatov, M.S., Gardiner, A.A., Bobrova, V.K., Milyutina, I.A., Huttunen, S, \& Troitsky, A.V. (2007) On the relationships of mosses of the order Hypnales, with special reference to taxa traditionally classified in the Leskeaceae. Pleurocarpous mosses: systematics and evolution. Systematics Association Special Volume 71: 177-213.

https://doi.org/10.1201/9781420005592.ch9

Ignatov, M.S., Heinrichs, J., Schäfer-Verwimp, A. \& Perkowsky, E.E. (2016b) The first record of a bryophyte in Upper Cretaceous amber from Taimyr, northern Siberia: Taimyrobryum martynoviorum gen. et sp. nov. (Bryopsida). Cretaceous Research 65: $25-31$. https://doi.org/10.1016/j.cretres.2016.04.005

Ignatov, M.S., Karasev, E.V. \& Sinitsa, S.M. (2011) Upper Jurassic mosses from Baigul (Transbaikalia, South Siberia). Arctoa 20: 4364.

https://doi.org/10.15298/arctoa.20.03

Ignatov, M.S., Karasev, E.V., Sinitsa, S.M. \& Maslova, E.V. (2013) New Bryokhutuliinia species (Bryophyta) with sporophytes from the Upper Jurassic of Transbaikalia. Arctoa 22: 69-78.

https://doi.org/10.15298/arctoa.22.10

Ignatov, M.S., Lamkovsky, P., Ignatova, E.A. \& Perkovsky, E.E. (2019) Mosses from Rovno amber (Ukraine), 4. Sphagnum heinrichsii, a new moss speices from Eocene. Arctoa 28 (1): 1-11.

https://doi.org/10.15298/arctoa.28.01

Ignatov, M.S. \& Perkovsky, E.E. (2011) Mosses from Rovno amber (Ukraine). Arctoa 20: 1-18.

https://doi.org/10.15298/arctoa.20.01

Ignatov, M.S. \& Perkovsky, E.E. (2013a) Mosses from Rovno amber (Ukraine). 2. Arctoa 22: 83-92.

https://doi.org/10.15298/arctoa.22.12

Ignatov, M.S. \& Perkovsky, E.E. (2013b) Mosses from Sakhalin amber (Russian Far East). Arctoa 22: 79-82.

https://doi.org/10.15298/arctoa.22.11

Ignatov, M.S., Schäfer-Verwimp, A., Perkovsky, E.E. \& Heinrichs, J. (2016c) Mosses from Rovno amber (Ukraine), 3. Pottiodicranum, a new moss genus from the Late Eocene. Arctoa 25: 229-235.

https://doi.org/10.15298/arctoa.25.18

Ignatov, M.S. \& Shcherbakov, D.E. (2007) Did Pleurocarpous mosses originate before the Cretaceous? In: Newton, A.E. \& Tangney, R. (Eds.) Pleurocarpous mosses: systematics and evolution. CRC Press, Boca Raton-London-New York (Systematic Association Special Volume 71), pp. 321-336.

https://doi.org/10.1201/9781420005592.ch16

Ignatov, M.S. \& Shcherbakov, D.E. (2009) A new fossil moss from the Lower Permian of the Russian Far East. Arctoa 18: $201-212$. https://doi.org/10.15298/arctoa.18.14

Ignatov, M.S. \& Shcherbakov, D.E. (2011a) Lower Cretaceous mosses from Khasurty (Baikal Area of South Siberia). Arctoa $20: 19-42$. https://doi.org/10.15298/arctoa.20.02

Ignatov, M.S. \& Shcherbakov, D.E. (2011b) Lower Triassic mosses from Yamanus (Mongolia). Arctoa 20: 65-80. https://doi.org/10.15298/arctoa.20.04

Ivanov, O.V., Maslova, E.V. \& Ignatov, M.S. (2018) Development of the sphagnoid areolation pattern in leaves of Palaeozoic protosphagnalean mosses. Annals of Botany (Oxford), n.s. 112 (5): 915-925. 
https://doi.org/10.1093/aob/mcy046

Janssens, J.A.P., Horton, D.G. \& Basinger, J.F. (1979) Aulacomnium heterostichoides sp. nov., an Eocene moss from south central British Columbia. Canadian Journal of Botany 57: 2150-2161.

https://doi.org/10.1139/b79-268

Jovet-Ast, S. (1967) Bryophyta. In: Boureau, E. (Ed.) Traité de Paléobotanique, Paris, 2. pp. 17-186.

Katagiri, T., Mukai, M. \& Yamaguchi, T. (2013) A new fossil moss Muscites kujiensis (Bryopsida) preserved in the Late Cretaceous amber from Japan. The Bryologist 116 (3): 296-301.

https://doi.org/10.1639/0007-2745-116.3.296

Kadlecová, V. (2020) Studium hub, ras a mechorostů z křidy Českého masivu a ostrova Jamese Rosse [Study of fungi, algae and bryophytes from the Cretaceous of the Bohemian Massif and James Ross Island]. Diplomová práce, Univerzita Karlova v Praze, Praha [In Czech].

Kenrick, P. \& Crane, P.R. (1997) The Origin and Early Diversification of Land Plants. Smithsonian Institution Press, Washington, DC, $441 \mathrm{pp}$.

Köck, C. (1939) Fossile Kryptogamen aus der eozänen Braunkohle des Geiseltales. Nova Acta Leopoldiana H, 6: 333-359 + figs. 3745.

Kodner, R.B. \& Graham, L.E. (2001) High temperature, acid-hydrolized remains of Polytrichum (Musci, Polytrichaceae) resemble enigmatic Silurian-Devonian tubular microfossils. American Journal of Botany 88 (3): 462-466.

https://doi.org/10.2307/2657111

Konopka, A.S., Herendeen, P.S. \& Crane, P.R. (1998) Sporophytes and gametophytes of Dicranaceae from the Santonian (Late Cretaceous) of Georgia, USA. American Journal of Botany 85: 714-723. https://doi.org/10.2307/2446542

Konopka, A.S., Herendeen, P.S., Merrill, G.L.S. \& Crane, P.R. (1997) Sporophytes and gametophytes of Polytrichaceae from the Campanian (Late Cretaceous) of Georgia, U.S.A. International Journal of Plant Sciences 158: 489-499. https://doi.org/10.1086/297459

Krassilov, V.A. (1973) Mesozoic bryophytes from the Bureja Basin, Far East of the USSR. Palaeontographica, Abteilung B 143: 95-105 + P1. 41-51.

Krassilov, V. (1982) Early Cretaceous flora of Mongolia. Palaeontographica, Abteilung B 181: 1-43.

Krassilov, V.A. \& Schuster, R.M. (1984) Paleozoic and mesozoic fossils. In: Schuster, R.M. (Ed.) New manual of bryology. Hattori Botanical Laboratory, Nichinan, pp. 1172-1193.

Kuc, M. (1972) Muscites eocenicus sp. nov., a fossil moss from the Allenby Formation (Middle Eocene), British Columbia. Canadian Journal of Earth Science 9 (5): 600-602. https://doi.org/10.1139/e72-049

Kuc, M. (1973a) Fossil flora of the Beaufort Formation, Meighen Island, NWT_Canada. Era 1: 1-44. https://doi.org/10.4095/103243

Kuc, M. (1973b) Plant macrofossils in Tertiary coal and amber from northern Lake Hazen, Ellesmere Island, N.W.T. Geological Survey of Canada, Paper 73-1 (B): 143.

https://doi.org/10.4095/104918

Kuc, M. (1974) Fossil mosses from the Bisaccate Zone of the mid-Eocene Allenby Formation, British Columbia. Canadian Journal of Earth Science 11: 409-421.

https://doi.org/10.1139/e74-037

Kučera, J. Kuznetsova, O.I., Manukjanová, A. \& Ignatov, M.S. (2019) A phylogenetic revision of the genus Hypnum: towards completion. Taxon 68: 628-660.

https://doi.org/10.1002/tax.12095

Lacey, W.S., Van Dijk, D.E. \& Gordon-Gray, K.D. (1975) Fossils plants from the Upper Permian in the Mooi River district of Natal, South Africa. Annals of the Natal Museum 2: 349-420.

Laenen, B., Shaw, B., Schneider, H., Goffinet, B., Paradis, É., Désamoré, A., Heinrichs, J., Villarreal, J.C., Gradstein, S.R., McDaniel, S., Long, D.G., Forrest, L.L., Hollingsworth, M.L, Crandall-Stotler, B.J., Davis, E.C., Engel, J., Konrat, M., von, Cooper, E.D., Patiño, J., Cox, C.J., Vanderpoorten, A. \& Shaw, A.J. (2014) Extant diversity of bryophytes emerged from successive post-Mesozoic diversification bursts. Nature Communications 5: 6134 [1-6].

https://doi.org/10.1038/ncomms6134

Lignier, O. (1914) Sur une mousse houillère a structure conservee. Bulletin de la Société Linnéenne de Normandie, ser. 6, 7: 128.

Linnaeus, C. von (1753) Species Plantarum, vol. 2. Imprensis Laurentii Salvii, Holmiae, pp. 561-1200.

Liu, L.J. \& Yao, Z.Q. (1996) Early Late Permian Angara flora from Turpan-Hami Basin. Acta Palaeontologica Sinice 35 (6): $644-671$. [In Chinese, English summary] 
Mamontov, Yu.S. \& Ignatov, M.S. (2019) How to rely on the unreliable: examples from Mesozoic bryophytes of Transbaikalia. Journal of Systematics and Evolution 57 (4): 339-360. https://doi.org/10.1111/jse.12483

Maslova, E.V., Mosseichik, Y.V., Ignatiev, I.A., Ivanov, O.V. \& Ignatov, M.S. (2012a) On the leaf development in Palaeozoic mosses of the order Protosphagnales. Arctoa 21: 241-264.

https://doi.org/10.15298/arctoa.21.24

Maslova, E.V., Ivanov, O.V. \& Ignatov, M.S. (2012b) On the distinction of two species of Palaeozoic moss genus Intia (Protospahgnales). Arctoa 21: 237-240. https://doi.org/10.15298/arctoa.21.23

Maslova, E.V., \& Ignatov, M.S. (2013) On the costa variation in leaves of Protosphagnalean mosses of Permian. Arctoa 22: 61-68. https://doi.org/10.15298/arctoa.22.09

Maslova, E.V., Ignatiev, I.A., Mosseichik, Y.V. \& Ignatov, M.S. (2016) Bulbosphagnum, a new form genus for brood bodies of mosses of the Palaeozoic order Protosphagnales. Arctoa 25: 314-331. https://doi.org/10.15298/arctoa.25.25

Mays, C., Tosolini, A.-M.P., Cantrill, D.J. \& Stilwell, J.D. (2015) Late Cretaceous (Cenomanian-Turonian) macroflora from the Chatham Islands, New Zealand: Bryophytes, lycophytes and pteridophytes. Gondwana Research 27: 1042-1060. https://doi.org/10.1016/j.gr.2014.03.017

Meyen, S.V. (1982) The Carboniferous and Permian floras of Angaraland (a synthesis). Biological Memoirs 7: 1-110.

Miller, N.G. (1980) Fossil mosses of North America and their significance. In: Taylor, R.J. \& Leviton, A.E. (Eds.) Mosses of North America. Pacific Division of the American Association for the Advancement of Sciences, San Francisco, pp. 9-36.

Miller, N.G. (1984) Tertiary and quaternary fossils. In: Schuster, R.M. (Ed.) New Manual of Bryology. Hattori Botanical Laboratory, Nichinan, pp. 1194-1232.

Moisan, P., Voigt, S., Schneider, J.W. \& Kerp, H. (2012) New fossil bryophytes from the Triassic Madygen Lagerstätte (SW Kyrgyzstan). Review of Palaeobotany and Palynology 187: 29-37. https://doi.org/10.1016/j.revpalbo.2012.08.009

Müller, C. (1848) Synopsis Muscorum Frondosorum omnium hucusque Cognitorum, Vol. 1, fasc. 3. Alb. Foerstner, Berlin, pp. 321-480. https://doi.org/10.5962/bhl.title.31

Nees von Esenbeck, C.G.D. (1833) Naturgeschichte der Europäischen Lebermoose. Vol. 1. pp. 1-348.

Newton, A.E., Wikstrom, N., Bell, N., Forrest L.L. \& Ignatov, M.S. (2007) Dating the diversification of the pleurocarpous mosses. In: Newton, A.E. \& Tangney, R. (Eds.) Pleurocarpous mosses: systematics and evolution. CRC Press, Boca Raton-London-New York (Systematic Association Special Volume 71), pp. 337-366. https://doi.org/10.1201/9781420005592.ch17

Neuburg, M.F. (1956) Discovery of leafy mosses in the Permian of the USSR. Doklady Akademii Nauk SSSR 102 (2): 321-324. [In Russian]

Neuburg, M.F. (1958a) Palaeozoic mosses of Angarida. Congreso geológico international. XX sessión. México, 1956: Sec. VII. Paleontología, Taxonomía y Evolución. México, pp. 97-106.

Neuburg, M.F. (1958b) Permian true mosses of Angaraland. Journal of the Palaeontological Society of India 3: 22-29.

Neuburg, M.F. (1960) Leafy mosses from the Permian deposits of Angarida. Transactions of the Geology Institute of the Academy of Sciences USSR (Moscow) 19: 1-104 + 78 pl. [In Russian]

Oostendorp, C. (1987) The bryophytes of the Paleozoic and Mesozoic. Bryophytorum Bibliotheca 34: 5-112 + plates I-XLIX.

Ottone, E.G., \& Archangelsky, S. (2001) A new bryophyte from the Upper Carboniferous of Argentina. Ameghiniana 38: $219-223$.

Pant, D.D. \& Basu, N. (1978) On two structurally preserved bryophytes from the Triassic of Nidpur, India. Palaeobotanist 25: 340-352.

Passalia, M.G. (2007) Nuevos registros para la flora cretácica descripta por Halle (1913) en lago San Martín, Santa Cruz, Argentina. Ameghiniana 44 (3): 565-595. [http://www.scielo.org.ar/scielo.php?script=sci_arttext\&pid=S0002-70142007000300006]

Pottier, J. (1925) Nouvelles recherches sur le développement de la feuille des Muscinées. Bulletin Société Botanique de France 72 : $629-689+$ pl. 11-14. https://doi.org/10.1080/00378941.1925.10832779

Puebla, G.G., Mego, N. \& Prámparo, M.B. (2012) Asociación de briofitas de la Formación La Cantera, Aptiano tardío, Cuenca de San Luis, Argentina. Ameghiniana 49(2): 217-229. https://doi.org/10.5710/AMGH.v49i2(504)

Reissinger, A. (1950) Die "Pollenanalyse" ausgedehnt auf alle Sedimentgesteine der geologische Vergangenheit. Zweiter teil. Palaeontographica, Abteilung B 90 (4-6): 99-126 + Tabl. 11-19.

Renauld, B. \& Zeiller, R. (1885) Sur des Mousses de l'époque houillère. Comptes Rendus Hebdomadaires des Séances de l'Académie des Sciences 100: 660-662. 
Renauld, B. \& Zeiller, R. (1888) Études sur les terrain houiller de Commentry. Livre deuxième. Flore fossile. Imprimateur Théolier and Cie, St. Étienne, pp. 3-366.

Riegel, W. \& Wilde, V. (2016) An Early Eocene Sphagnum bog at Schoningen, northern Germany. International Journal of Coal Geology 159: $57-70$. https://doi.org/10.1016/j.coal.2016.03.021

Ricardi-Branco, F., Sampaio Costa, J., Christiano da Souza, I.C., Ronh, R., Longhim, M. \& Faria, R.S. (2013) Bryophytes associated with Pennsylvanian periglacial environments in southern Gondwana (São Paulo State, Itararé Group, Paraná Basin)-Brazil. New Mexico Museum of Natural History and Science, Bulletin 60: 343-347.

Ricardi-Branco, F., Rohn, R., Longhim, M.E., Sampaio Costa, J., Milani Martine, A. \& Christiano-de-Souza, I.C. (2016) Rare Carboniferous and Permian glacial and non-glacial bryophytes and associated lycophyte megaspores of the Parana Basin, Brazil: a new occurrence and paleoenvironmental considerations. Journal of South American Earth Sciences 72: 63-75.

https://doi.org/10.1016/j.jsames.2016.07.014

Robinson, H.E. (1965) Venezuelan bryophytes collected by Julian A. Steyermark. Acta Botanica Venezuelica 1: $73-83$.

Rubinstein, C.V., Gerrienne, P., Puente, G.S. de la, Astini, R.A. \& Steemans, P. (2010) Early Middle Ordovician evidence for land plants in Argentina (eastern Gondwana). New Phitologist 188 (2): 306-309.

https://doi.org/10.1111/j.1469-8137.2010.03433.x

Savoretti, A., Bippus, A.C., Stockey, R.A., Rothwell, G.W. \& Tomescu, A.M.F. (2018) Grimmiaceae in the Early Cretaceous: Tricarinella crassiphylla gen. et sp. nov. and the value of anatomically preserved bryophytes. Annals of Botany (Oxford), n.s. 121 (7): $1275-$ 1286.

https://doi.org/10.1093/aob/mcy015

Schimper, W.P. (1856) Corollarium Bryologiae Europaeae. E. Schweizerbart, Stuttgartiae, 140 pp.

Schimper, W.P. (1860) Icones morphologicae atque organographicae instructionum Synopsi Muscorum Europaeorum. E. Schweiserbarrt, Stuttgartiae, $26 \mathrm{pp}+11$ tabs.

Schneider, H., Schuettpelz, E., Pryer, K.M., Cranfill, R., Magallon, S. \& Lupia, R. (2004) Ferns diversified in the shadow of the angiosperms. Nature 428: 553-557.

https://doi.org/10.1038/nature02361

Schuster, R.M. \& Janssens, J.A. (1989) On Diettertia, an isolated Mesozoic member of the Jungermanniales. Review of Palaeobotany and Palynology 57: 277-287.

https://doi.org/10.1016/0034-6667(89)90025-0

Schwägrichen, C.F. (1826) Species Muscorum Frondosorum, Supplement 2, vol. 2, sect. 1. Leipzig, Barth. pp. 1-79+ plates 151-175.

Shaw, A.J., Cox, C.J., Goffinet, B., Buck, W.R. \& Boles, S.B. (2003) Phylogenetic evidence of a rapid radiation of pleurocarpous mosses (Bryophyta). Evolution 57: 2226-2241. https://doi.org/10.1111/j.0014-3820.2003.tb00235.x

Shelton, G.W.K., Stockey, R.A., Rothwell, G.W. \& Tomescu, A.M.F. (2015) Exploring the fossil history of pleurocarpous mosses: Tricostaceae fam. nov. from the Cretaceous of Vancouver Island, Canada. American Journal of Botany 102: 1883-1900. https://doi.org/10.3732/ajb.1500360

Shelton, G.W.K., Stockey, R.A., Rothwell, G.W. \& Tomescu, A.M.F. (2016) Krassiloviella limbelloides gen. et sp. nov.: additional diversity in the pleurocarpous moss family Tricostaceae (Valanginian, Vancouver Island, British Columbia). International Journal of Plant Sciences 177 (9): 792-808.

https://doi.org/10.1086/688707

Smoot, E.L. \& Taylor, T.N. (1986) Structurally preserved fossil plants from Antarctica. II. A Permian moss from the Transantarctic Mountains. American Journal of Botany 73: 1683-1691. https://doi.org/10.1002/j.1537-2197.1986.tb09699.x

Srebrodolskaya, I.N. (1980) Novye pozdnemesozoiskie listostebelnye mkhi iz Zabaikaliya [New Late Mesozoic mosses from Transbaikalia] Trudy Vsesoyuznogo Nauchno-Issledovatelskogo Geologicheskogo Instituta 204: 27-28. [In Russian]

Steere, W.C. \& Murray, B.M. (1976) Andreaeobryum macrosporum, a new genus and species of Musci from northern Alaska and Canada. Phytologia 33: 407-410. https://doi.org/10.5962/bhl.part.16794

Taylor, W.A. \& Strother, P.K. (2008) Ultrastructure of some Cambrian palynomorphs from the Bright Angel Shale, Arizona, USA. Review of Palaeobotany and Palynology 151: 41-50. https://doi.org/10.1016/j.revpalbo.2008.01.012

Thomas, B.A. (1972) A probable moss from the Lower Carboniferous of the Forest of Dean, Gloucestershire. Annals of Botany 36: $155-161$.

https://doi.org/10.1093/oxfordjournals.aob.a084568 
Tomescu, A.M.F. (2016) The Early Cretaceous Apple Bay flora of Vancouver Island: a hotspot of fossil bryophyte diversity. Botany 94 (9): 683-695.

https://doi.org/10.1139/cjb-2016-0054

Tomescu, A.M.F., Bomfleur, B., Bippus, A.C. \& Savoretti, A. (2018) Why are bryophytes so rare in the fossil record? A spotlight on taphonomy and fossil preservation. Transformative Paleobotany: 375-416.

https://doi.org/10.1016/B978-0-12-813012-4.00016-4

Townrow, A. (1959) Two Triassic bryophytes from South Africa. Journal of South African Botany 25: 1-22+4 Tabs.

Turutanova-Ketova, A.I. (1958) Floristic characteristics of some Lower Mesozoic deposits on the eastern slope of Middle Urals. Botanichesky Zhurnal 43 (5): 664-678. [In Russian]

Vanderpoorten, A., Hedenäs, L., Cox, C.J. \& Shaw, A.J. (2002) Circumscription, classification, and taxonomy of Amblystegiaceae (Bryopsida) inferred from nuclear and chloroplast DNA sequence data and morphology. Taxon 51: 115-122. https://doi.org/10.2307/1554968

Vera, E.I. (2010) Livingstonites gabrielae gen. et sp. nov., permineralized moss (Bryophyta: Bryopsida) from the Aptian Cerro Negro Formation of Livingston Island (South Shetland Islands, Antarctica). Ameghiniana 48 (1): 122-128. https://doi.org/10.5710/AMGH.v48i1(477)

Villarreal, A.J.C., Crandall-Stotler, B.J., Hart, M.L., Long, D.G. \& Forrest L.L. (2016) Divergence times and the evolution of morphological complexity in an early land plant lineage (Marchantiopsida) with a slow molecular rate. New Phytologist 209 (4): $1734-1746$. https://doi.org/10.1111/nph.13716

Wang, Y.D. \& Wu, X.W. (2007) Records and diversity of the fossil bryophytes in China. Chenia 9: 61-72.

Weitschat, W. \&Wichard, W. (2002) Atlas of plants and animals in Baltic amber. München, Friedrich Pfeil, 256 pp.

Welleman, C. (1995) "Phytodebris" from Scottish Silurian and Lower Devonian continental deposits. Review of Palaeobotany and Palynology 84: 255-279. https://doi.org/10.1016/0034-6667(94)00115-Z

Wilson, L.R. \& Webster, R.M. (1946) Plant microfossils from a Fort Union coal of Montana. American Journal of Botany 33: $271-278$. https://doi.org/10.1002/j.1537-2197.1946.tb10375.x

Wilson, R., Heinrichs, J., Hentschel, J., Gradstein, S.R. \& Schneider, H. (2007) Steady diversification of derived liverworts under Tertiary climatic fluctuations. Biological Letters 3: 566-569. https://doi.org/10.1098/rsbl.2007.0287

Wittlake, E.B. (1968) Fossil mosses from the Upper Wilcox (Lower Eocene) of Arkansas. American Midland Naturalist 80: $543-547$. https://doi.org/10.2307/2423547

Wu, S.Q. (1999) A preliminary study of the Jehol flora from western Liaoning). Palaeoworld 11: 7-57. [In Chinese, English summary]. [http://english.nigpas.cas.cn/sp/Palaeoworldbackup/vol11/201103/P020110303334173856367.pdf] [http://english.nigpas.cas.cn/sp/ Palaeoworldbackup/vol11/201103/P020110303332812223534.pdf]

Wu, X.-W., Wu, X.-Y. \& Wang, Y.-D. (2000) Two new forms of Bryiidae (Musci) from the Jurassic of Junggar Basin in Xinjiang, China. Acta Palaeontologica Sinica 39 (Suppl.): 167-175.

Yang, R.D., Mao, J.R., Zhang, W.H., Jiang, L.J. \& Gao, H.A. (2004) Bryophyte-like fossil (Parafunaria sinensis) from Early-Middle Cambrian Kaili Formation in Guizhou Province, China. Acta Botanica Sinica 46: 180-185. 